\section{De colônia de imigrantes a um polo gastronômico: uma pesquisa institucional documental}

\author{
Danielle Ferraz Vieira e Márcio Jacometti
}

\section{RESUMO}

O campo organizacional é resultado de interações ao longo do tempo entre organizações, indivíduos e o próprio contexto onde estão inseridos. Os fundamentos da nova teoria institucional permitem essa leitura e, nesse sentido, o objetivo desta pesquisa foi identificar que fatores institucionais influenciaram a formação do Polo Gastronômico no Bairro de Santa Felicidade, na cidade de Curitiba, Capital do Paraná, Brasil. Para atingir este propósito, foi utilizada a estratégia de pesquisa qualitativa, na qual se adotou como método a pesquisa documental sobre o setor turístico-gastronômico do referido bairro, considerando um recorte seccional com avaliação longitudinal no período de 1878 a 2020. Os dados coletados foram analisados por meio da técnica de análise de conteúdo temática e as categorias analíticas utilizadas foram o empreendedorismo institucional no nível da ação e as instituições no contexto. Concluiu-se que o empreendedorismo institucional desempenhado pelos atores sociais permitiu a evolução do campo organizacional desta localidade, possibilitando a formação do Polo Gastronômico investigado.

Palavras-chave: contexto institucional; empreendedorismo institucional; instituições; pesquisa documental.

\section{From immigrant colony to a gastronomic pole: a documental institutional research}

\section{ABSTRACT}

The organizational field is the result of interactions over time between organizations, individuals and the context in which they are inserted. The foundations of the new institutional theory allow this reading and, in this sense, the objective of this research was to identify which institutional factors influenced the formation of the Gastronomic Pole in the Santa Felicidade District, in the city of Curitiba, Capital of Paraná, Brazil. To achieve this purpose, the qualitative research strategy was used, in which documentary research on the tourist-gastronomic sector of the referred neighborhood was adopted as a method, considering a sectional profile with longitudinal evaluation, in the period from 1878 to 2020 . The data collected were analyzed using the thematic content analysis technique and the analytical categories used were institutional entrepreneurship at the action level and institutions in the context. It was concluded that the institutional entrepreneurship performed by the social actors allowed the evolution of the organizational field in this location, enabling the formation of the investigated Gastronomic Pole.

Keywords: institutional context; institutional entrepreneurship; institutions; documentary research.
Recebido em: 23/05/2020 Revisado em: 14/06/2020 Aprovado em: 30/07/2020

D) Check for updates

Danielle Ferraz Vieira (iD, Universidade Tecnológica Federal do Paraná, Brasil

Mestranda em Administração,

Universidade Tecnológica Federal do Paraná, Brasil

vieira.d.ferraz@gmail.com

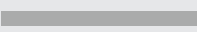

Márcio Jacometti (iD), Universidade Tecnológica Federal do Paraná, Brasil

Doutor em Administração,

Universidade Federal do Paraná, Brasil

jacometti@utfpr.edu.br 
Introdução

A área de Estudos Organizacionais [EOR] propõe debates que abordam as organizações e os indivíduos nelas inseridos. Thiollent (2014), ao apresentar esse escopo, aponta diferentes perspectivas, uma vez que é necessário considerar a existência de tipologias distintas como entidades públicas, privadas e as de sociedade civil. Nesse sentido, uma ampla análise pode ser realizada, ao investigar questões tanto do ambiente interno como das interações que acontecem junto ao ambiente externo. Observa-se, assim, práticas, princípios, estruturas, processos e fatores diversos que envolvem atores múltiplos. Ainda segundo o autor (2014, p. 3), "as organizações agem e evoluem em função de fatores de competição, posições de mercado, estratégias de atividades e interações em redes".

Levando em consideração esses aspectos, a perspectiva institucional de análise tem sido amplamente utilizada como fundamentação teórica para o entendimento dos fenômenos sociais que permeiam as organizações.

Essa realidade é expressada por Jacometti, Castro, Gonçalves e Costa (2016, p. 429), ao comentar que:

Na teoria institucional, os norteadores das práticas sociais são as
instituições que configuram e conferem certas probabilidades maiores
de ação em detrimento de outras. Não se trata de predeterminação,
no sentido de que as coisas vão acontecer de modo uniforme,
independente da vontade dos atores sociais, e sim que elas nascem
numa realidade institucionalizada com tipificações que dizem como as
coisas devem ser, exercendo assim pressão de configuração.

Por isso, faz-se necessário aprofundar o entendimento sobre fatores internos e externos aos quais as organizações estão submetidas, como crenças, práticas isomórficas, legitimação e institucionalização, por exemplo. Sendo assim, a teoria institucional pode ser capaz de auxiliar o entendimento de tal ambiente. Zucker (1987) afirma que essa abordagem teórica configura uma importante ferramenta para a compreensão da complexa estrutura e das pressões institucionais, ou ainda de elementos legitimadores sofridos pelas organizações forçadas a seguir um determinado padrão. Por outro lado, conforme propõe DiMaggio (1988), o entendimento sobre processos de criação e transformação de instituições pode ser realizado ao analisar tanto os atores sociais, quanto a capacidade de empreender institucionalmente.

Posto isto, essa perspectiva teórica pode ser empregada em diversos estudos que busquem o entendimento sobre contextos institucionais. Entre as possibilidades, tem-se a utilização para compreensão de organizações em ambiente turístico. O Turismo, em si, é uma atividade de cunho socioeconômico, responsável por gerar divisas, renda e bem-estar. Trata-se de uma atividade que interliga diversos setores e atores da economia e atende a demandas e motivações distintas.

Essa versatilidade permitiu ao setor turístico reagir com enfrentamento mesmo diante das fortes crises econômicas. O Serviço Brasileiro de Apoio às Micro e Pequenas Empresas [SEBRAE] aponta que, mediante dados da Organização Mundial do Turismo [OMT], no ano de 2016, esse setor foi responsável pela geração de 1 a cada 11 empregos, pela movimentação de 1,84 bilhão de pessoas e realização de US\$1,5 trilhão em exportações, 
representando 10\% do Produto Interno Bruto [PIB] mundial (SEBRAE, 2018). No caso do Brasil, segundo pesquisa realizada pela Oxford Economic, em 2017, a atividade turística resultou em um acréscimo de $7 \%$ do valor injetado na economia brasileira, quando comparado ao ano anterior, saltando de US\$ 152,2 bilhões para US\$ 163 bilhões, o que representa o equivalente a 7,9\% do PIB nacional (Ministério do Turismo, 2017).

Em nível municipal, a capital Paranaense apresenta também números expressivos. Em 2018, o Instituto Municipal de Turismo [IMT] realizou a pesquisa de demanda turística de Curitiba. Dentre alguns dos aspectos abordados, estima-se que a cidade tenha recebido em torno de 5,5 milhões de turistas, com tempo médio de permanência de quatro dias e média diária de gastos de aproximadamente 275 reais (IMT, 2018).

Assim, a partir desta breve introdução, propõe-se como objeto de pesquisa a ser explorado, o Setor Turístico-Gastronômico do Bairro de Santa Felicidade, na cidade de Curitiba, Paraná, Brasil. O fenômeno de sua configuração e formação se insere como oportunidade para a presente investigação.

O Polo Gastronômico de Santa Felicidade situa-se ao longo da Avenida Manoel Ribas, a partir do portal de Santa Felicidade até a rua Ângelo Stival, abrangendo 32 empreendimentos ligados à gastronomia, entre eles, restaurantes diversos, panificadoras (cafés/confeitarias), sorveteria e petiscaria (Curitiba, 2017).

De acordo com o Prefeito de Curitiba, Rafael Greca, e o Vereador Curitibano Mauro Ignácio, o Bairro de Santa Felicidade é apontado como importante centro de comércio e um dos maiores Polos Gastronômicos do Brasil, desencadeando constante fluxo de turistas. Flora Madalosso, empresária local, enfatiza a importância dos restaurantes para o setor, ao argumentar que somente em seus estabelecimentos, os Restaurantes Madalosso e Velho Madalosso, são atendidos mensalmente cerca de 100 mil pessoas (Curitiba, 2017).

Diante da relevância do Turismo enquanto atividade socioeconômica e da importância de compreender as organizações que compõem esse setor, essa pesquisa tem como objetivo identificar quais fatores institucionais influenciaram na formação do Polo Gastronômico, no Bairro de Santa Felicidade, na cidade de Curitiba, Paraná, Brasil, no período de 1878 a 2020.

Conforme Gândara, Gimenes e Mascarenhas (2009, p. 181):

Turismo gastronômico: uma vertente do turismo cultural no qual
o deslocamento de visitantes se dá por motivos vinculados às
práticas gastronômicas de uma determinada localidade. O turismo
gastronômico pode ser operacionalizado a partir de atrativos como
culinária regional, eventos gastronômicos e oferta de estabelecimentos
de alimentos e bebidas diferenciados, bem como roteiros, rotas e
circuitos gastronômicos.

É importante ressaltar que ao enfatizar, nessa localidade, a tipologia Turismo Gastronômico, não se pretende excluir outras formas de turismo existentes nesse ambiente; ao contrário: significa ter uma preocupação didática, que visa um direcionamento conforme o enfoque da pesquisa. Vale ressaltar que, conforme Barretto e Rejowski (2009, p. 15), diante da pluralidade humana, "toda e qualquer tipologia constitui apenas uma 
ferramenta epistemológica que os pesquisadores utilizam conforme suas necessidades [...]".

Sob a ótica da relevância teórica, este estudo mostra-se pertinente visto que, ao efetuar a busca por referenciais teóricos, constatou-se que, embora a teoria institucional seja amplamente discutida na Administração, existe uma lacuna a ser explorada no que tange a abordagem voltada para organizações em contexto turístico. A pesquisa inicial considerou o quantitativo referente às produções acadêmicas que utilizam essa perspectiva teórica. Sendo assim, foi utilizada a ferramenta de pesquisa Google Scholar, delimitando o período entre 2010 a 2019, no qual os argumentos de busca poderiam ocorrer em qualquer parte do texto. O termo "institutional theory" resultou 40.300 publicações, contra apenas 741 resultados quando utilizadas conjuntamente as tags "institutional theory, institutional entrepreneurship and tourism". Esse quantitativo se mostrou ainda mais limitado ao empregar os respectivos termos em português, totalizando apenas 32 ocorrências. Falaster, Zanin e Guerrazzi (2017) corroboram com os números encontrados, uma vez que, conforme os autores, ainda são restritos os estudos ligados ao turismo que se apropriam da perspectiva institucional, além de defenderem que essa é uma lacuna a ser explorada.

Ademais, dentro do panorama nacional foi considerado o termo "polo gastronômico", resultando 548 estudos. Todavia, ao pontuar os termos "polo gastronômico" e "teoria institucional", apenas duas ocorrências foram observadas, sendo elas o estudo de Zaneti (2012), realizado em Brasília, que descreve a valorização de produtos tradicionais (pequi) na alta gastronomia, e a pesquisa de Freitas (2018), feita em Uberlândia. A última analisou as múltiplas manifestações culturais no ambiente de trabalho gastronômico, bem como o reflexo destas no preparo de pratos. Desta forma, os estudos observados possuem abordagens distintas àquelas propostas nesta pesquisa.

Frente ao exposto, este estudo mostra-se pertinente ao buscar elementos empíricos que possam dialogar com essa teoria, uma vez que investiga fatores institucionais que influenciaram a formação de organizações no nível setorial, destacando a avaliação longitudinal e resgatando mais de um século de história.

Quanto à relevância prática, uma vez que o estudo pondera sobre organizações ligadas à atividade turística e reconhece a importância dos atores para composição do Setor, ao identificar os fatores institucionais que influenciaram a formação do referido Polo Gastronômico, espera-se que a partir dos resultados obtidos seja possível fornecer insights para novas pesquisas e ainda auxiliar esta e demais localidades quanto a ações futuras, ligadas, por exemplo, ao planejamento da atividade turística, estratégias de marketing de destinos turísticos e questões relacionadas ao bem-estar das comunidades locais.

Assim, findada a introdução, este estudo segue estruturado em mais quatro seções: Perspectiva teórica, direcionada pela teoria institucional; Metodologia, na qual são apresentados os passos metodológicos; Análise dos dados e discussão dos resultados, em consonância com a perspectiva teórica apontada; e, ao final, apresentam-se as Considerações finais. 


\section{Perspectiva teórica}

A partir de influências dos sociólogos europeus Émile Durkheim e Max Weber, Talcott Parsons torna-se um dos precursores da teoria institucional. Entre as obras do autor, França (2009) sinaliza a importância do livro The structure of social action (1937), a qual reside uma sociologia das organizações, fato que contribui para o debate sobre instituições. Posteriormente, Regatieri (2019, p. 194), menciona que em The social system (1951), "[...] Parsons concebe três sistemas de ação: personalidade, sociedade e cultura". Domingues (2001), ao discorrer sobre a Sociologia de Parsons, argumenta que a ação social é defendida como qualquer conduta humana, cuja motivação ocorre a partir de um evento externo. Já o sistema social representa a totalidade integrada, que abrange tanto o indivíduo, como o meio e a sociedade. Na existência de um problema, em qualquer uma dessas partes, a totalidade do sistema será atingida.

Ainda, atribui-se a Phillip Selznick o pioneirismo da abordagem institucional nos estudos organizacionais, por meio de uma importante obra lançada em 1957, intitulada Leadership in Administration (Goulart, Vieira, \& Carvalho, 2005). Em conformidade, Holanda (2003), aponta que nesse período de transição da década de 1950 para 1960, as organizações, antes vistas de forma isolada, agora passam a ser analisadas como uma estrutura conectada e interdependente do meio onde estão inseridas.

Não obstante as diferenças e variações de enfoque, a teoria institucional se destaca das demais teorias organizacionais por colocar o ambiente como determinante central da estrutura organizacional, analisando, porém, a interação organização-ambiente sob o prisma dos elementos culturais - valores, símbolos, mitos, sistemas de crenças e programas profissionais (Holanda, 2003, p. 26).

O institucionalismo sociológico surge no final da década de 1970 e defende que as novas instituições devem surgir em um contexto já permeado por instituições, servindo como modelos para as demais. Além disso, considera os indivíduos como atores sociais dentro de um ambiente social específico (Hall \& Taylor, 1996). Sendo assim, o contexto institucional é formado pela reunião de acontecimentos que influenciam as organizações (Hall, 2004/1972). Essa visão vai ao encontro do posicionamento de Berger e Luckmann (2004/1966, p. 76), no qual "a ordem social existe unicamente como produto da atividade humana". Nesse cenário, Powell e DiMaggio (1991) compilam importantes estudos da época, na obra intitulada The new institutionalism in organizational analysis, avaliando a evolução das organizações por meio da perspectiva institucional, ou institucionalismo organizacional, como ficou conhecido. Os autores também fornecem especial atenção à criação e mudança de instituições, levando em consideração os aspectos históricos e o papel dos indivíduos envolvidos nesses processos.

Vasconcelos (2004) observa que, em estudos de estratégia empresarial, a realidade social, em grande maioria, por muito tempo foi observada segundo uma abordagem objetivista. Todavia, a partir da década de 1970, novos estudos são propostos, fomentando o debate segundo uma perspectiva menos objetivista e mais interpretativista. Uma epistemologia construtivista 
focada na estratégia empresarial traz esse caráter interpretativista, procurando entender os sentidos e consequências das ações. Além disso, o autor analisa também como os elementos estão ligados, dando ênfase aos atores, interpretando a dinâmica social que ocorre entre eles e como estes percebem a realidade. A possibilidade de múltiplos contextos dentro de um único ambiente institucional também é considerada, de forma a não descartar aspectos históricos no processo de interpretação.

Scott (1992/1981, pp. 157-158), por sua vez, defende uma distinção entre ambiente institucional e ambiente técnico. Para ele, o ambiente institucional se dá "pela elaboração de normas e exigências a que as organizações se devem conformar se querem obter apoio e legitimidade do ambiente", enquanto que ambiente técnico se refere a oferta de "um produto ou serviço que é trocado no mercado e às organizações que são premiadas pelo controle eficiente e eficaz do processo de trabalho".

Quanto à definição de instituições, ainda conforme Scott (2008/1995, p. 48), "Instituições são compostas por elementos reguladores, normativos e cultural-cognitivos que, juntamente com atividades e recursos associados, fornecem estabilidade e significado para a vida social".

De acordo com o mesmo autor, o pilar regulador institui ações de restrição ou capacitação de comportamentos em um determinado contexto, por meio de processos regidos por regras, ações monitoradas e ainda pela aplicação de sanções, sejam elas punitivas ou compensatórias. A operacionalização deste pilar pode ocorrer tanto por mecanismos informais como formais. $\mathrm{O}$ pilar normativo, por sua vez, está relacionado à ideia de prescrição, avaliação e obrigação, aos quais os membros de um contexto social estão submetidos, fornecendo diretrizes para as ações, estabelecendo definições quanto a direitos e obrigações sociais. Há uma tendência de que instituições formadas nesse pilar sejam partidárias de crenças e valores comuns, incluindo a concepção de moralidade. E, por fim, o pilar cultural-cognitivo, que está fortemente conectado à concepção de realidade socialmente construída, uma vez que existe o alinhamento do conhecimento cultural, baseado num processo de interpretação subjetiva que ao mesmo tempo é moldado por aspectos externos. Nesse caso, existe uma interação entre os atores, e as ações são compartilhadas por serem consideradas certas.

Para Scott (2008/1995), a institucionalização é desencadeada à medida que, ações repetidas e dotadas de significado em comum por membros de uma determinada estrutura social, passam a ser perpetuadas ao longo do tempo, tornando-se habituais. Por conseguinte, os autores Nascimento, Rodrigues e Megliorini (2010, p. 5) defendem que "[...] é de se presumir que a total institucionalização possa depender de dois fatores: baixa resistência de ator ou conjunto de atores e divulgação continuada do feito e/ou dos benefícios auferidos e possíveis de mensuração e evidenciação".

Vale destacar aqui o aspecto de institucionalização em duas visões: de um lado os autores Berger e Luckmann (2004/1966), Meyer e Rowan (1977) e Zucker (1977), cuja visão estebelece que os atores individuais conduzem o processo. Por outro lado, tem-se Tolbert e Zucker (1998), cuja visão determina que as organizações são responsáveis por essa mudança, incorrendo em três momentos distintos: a habitualização, objetivação e sedimentação. 
Na acepção de Jepperson (1991), as instituições tendem a resistir à mudança, promovendo sua automanutenção e restauração. Já os estudos de Lawrence, Winn e Jennings (2001) apresentam as fases da institucionalização (inovação, difusão, legitimação e desinstitucionalização), considerando o aspecto temporal (ritmo e estabilidade) ditado pelos mecanismos adotados no processo (influência, força, disciplina e dominação). Na concepção de Oliver (1992), a desinstitucionalização pode ocorrer quando práticas, antes institucionalizadas, perdem força dentro das organizações. Entre os fatores que impulsionam a mudança institucional podem ser citados os mecanismos de ordem política, funcional ou ainda social. Nesse sentido, de acordo com a autora, durante o período de desinstitucionalização as organizações encontram-se no chamado vácuo institucional, até que novas práticas sejam adotadas e legitimadas.

Por outro lado, Machado-da-Silva, Fonseca e Crubellate (2010), ao contrário do que acreditam ser a visão determinística de Tolbert e Zucker (1998), defendem uma lógica de institucionalização recursiva, de forma intersubjetiva, focada nos elementos estrutura, agência e interpretação. Ou seja, agência e estrutura ocorrem simultaneamente, uma vez que a interpretação desse sistema é realizada pelos atores sociais. Assim, Machado-da-Silva, Fonseca e Crubellate (2010) advogam que pode ocorrer tanto a reprodução de estruturas quanto a reinterpretação destas, incorrendo na possibilidade de mudança.

Quanto ao campo organizacional, num primeiro momento, emerge de um ambiente com instituições trabalhando de forma isolada, mas à medida que novos arranjos são formandos e as conexões aumentadas, um maior nível de institucionalização é atingido (Holanda, 2003).

Conforme DiMaggio e Powell (2005/1983, p. 76), o campo organizacional pode ser compreendido como "aquelas organizações que, em conjunto, constituem uma área reconhecida da vida institucional: fornecedores-chaves, consumidores de recursos e produtos, agências reguladoras e outras organizações que produzem serviços ou produtos similares". Ademais, os autores, a partir de uma contextualização inicial, mencionam a burocratização e racionalização como formas de controlar os mercados competitivos e o Estado. Mas, sinalizam também a existência de novos agentes racionalizadores, capazes de direcionarem mudanças nas organizações, tornando-as mais similares entre elas sem, no entanto, voltarem-se necessariamente a questões de competitividade e eficiência. De modo que, à medida que campos organizacionais bem estruturados emergem, existe um movimento em direção à homogeneidade estrutural, cultural e de resultados.

Segundo os autores supracitados, a homogeneização entre organizações pode ser mais facilmente entendida por meio da definição de isomorfismo. Esse processo leva as empresas a estabelecer similaridade está dividido em isomorfismo competitivo e isomorfismo institucional.

Enquanto o isomorfismo competitivo está atrelado à noção de competição de mercado, o isomorfismo institucional inclina-se a compreender as pressões diversas sofridas pelas organizações, em resposta às questões políticas, de legitimação, normativas e de ordenamento social e econômico. Este último, por sua vez, se divide em três tipos: coercitivo, mimético e normativo. 
O isomorfismo institucional do tipo coercitivo está ligado às respostas a ordens governamentais e influências políticas, adequações legais e fiscais, políticas afirmativas, entre outras. Trata-se de uma espécie de protocolo a ser seguido e sua aplicação pode ocorrer de maneira coercitiva, persuasiva ou como uma forma de pertencimento.

$\mathrm{O}$ isomorfismo institucional mimético pode ser entendido como um processo de imitação de uma organização em relação a outra, ocorrendo como resposta às incertezas, uma vez que acredita que determinada organização que confere um modelo de boas práticas possui uma oferta de melhores condições de trabalho, seja pela experiência de organizações com maior tempo de vida ou ainda como um direcionamento para organizações tidas como exemplos de sucesso.

No caso do isomorfismo institucional normativo, este se constitui pela profissionalização, pois destaca a importância da educação formal e das redes profissionais. Essa similaridade entre os pares é visto como um diferencial, uma vez que facilita a comunicação entre organizações, a competição por status, e ainda pode estar atrelado a fatores de elegibilidade para contratos tanto públicos como privados.

Assim, dentro do contexto isomórfico institucional, percebe-se que há um ponto de convergência encontrado entre os três tipos, que se refere à busca por legitimação das organizações.

$\mathrm{Na}$ perspectiva institucional organizacional, a legitimidade assume importante papel quanto a sobrevivência de organizações, bem como a perpetuação de instituições (Scott, 2008/1995).

Outro aspecto importante a ser considerado dentro do campo organizacional é o indivíduo enquanto empreendedor institucional, que desempenha uma função social dentro da estrutura na qual está inserido. Logo, quanto maior a proximidade dos atores com recursos, maior a possibilidade de promover mudanças no ambiente (Battilana, 2006).

O termo empreendedorismo institucional tem origem no trabalho de Eisenstadt (1980) e ganha força na teoria organizacional por meio dos estudos de DiMaggio em 1988 (Avrichir \& Chueke, 2011). Para DiMaggio (1988), empreendedores institucionais são atores capazes de criar ou transformar instituições dentro de um campo emergente.

Hardy e Maguire (2008) defendem que empreendedores institucionais podem ser indivíduos, organizações, redes e movimentos sociais. Brunstein, Rodrigues e Kirschbaum (2008) argumentam que organizações tidas como empreendedoras institucionais são aquelas capazes de gerar inovação social. Neste estudo, o significado de inovação social é o conferido por Lévesque (2002), ou seja, uma forma de promover a reorganização de padrões sociais ou ainda como resposta à problemas de ordem social. Conforme Borges (2014, p. 52):

[...] o empreendedorismo institucional pode ser entendido como a linha de pesquisa da teoria institucional que mais se aproxima da tentativa de responder o porquê, de que forma e quais os motivos que levam indivíduos e organizações, dotados de características e habilidades previamente delineados, a desbravar oportunidades. Essas oportunidades encontram-se, em muitos casos, subjacentes 
as vias institucionais (exemplo: cooptação de pessoas influentes; brechas em legislações; crenças e mitos populares, crises), sendo tanto utilizadas como condutoras de mudança, como também mantenedoras do equilíbrio no ambiente institucional e técnico.

Nesse sentido, há literaturas que abordam as características e o papel do indivíduo enquanto empreendedor institucional (Battilana, 2006; Li, Feng, \& Jiang, 2006; Mutch, 2007; Svejenova, Mazza, \& Planellas, 2007; Czarniawska, 2009; Avrichir \& Chueke, 2011; Smothers, Murphy, Novicevic, \& Humphreys, 2014; Arruda, 2016). A partir de algumas dessas leituras, Avrichir e Chueke (2011), sugerem que a ação do empreendedor institucional individual pode ser categorizada de duas maneiras: considerando a sua extensão, em que as pequenas ações são responsáveis por gerar grandes mudanças, e de outro, na qual a concentração de grandes esforços proporcionam resultados de menor impacto.

Circundam, ainda, em torno da ação institucional empreendedora, discussões referentes ao chamado paradoxo da imersão. Conforme Baratter, Ferreira e Costa (2010, p. 240), "a imersão é um tema importante no institucionalismo organizacional porque evidencia a força das instituições sobre a ação dos atores, mas se tem deixado de lado a influência exercida pelos atores nas instituições". As autoras analisam o empreendedorismo institucional como ação intencional, promovendo a discussão em torno dos aspectos de posicionamento do ator, da configuração do campo organizacional, da capacidade de ação e da reflexividade desses atores sociais. Autores como Battilana (2006), Leca, Battilana e Boxenbaum (2009), Avrichir e Chueke (2011) argumentam que a posição ocupada pelo ator social irá refletir na forma como as ações de empreendedorismo institucional serão empregadas no campo organizacional.Alguns empreendedores institucionais imersos no campo conseguem ainda promover mudança, ao persuadirem outros indivíduos também imersos através de mecanismos de teorização e difusão. A teorização consiste em propor uma ação alternativa frente a uma prática institucionalizada que fracassou, ou que não oferece mais benefícios ao campo organizacional. A difusão, por outro lado, é atingida quando a prática é adotada no campo organizacional (Suddaby \& Greenwood, 2005).

Por fim, a perspectiva institucional ainda abarca discussões sobre o conceito de institutional work, compreendendo, além dos processos de criação e manutenção, a ruptura de instituições, cuja ênfase é no modelo de microanálise institucional através da lógica bottom-up, ao considerar a capacidade de ação de atores imersos no campo organizacional (Lawrence \& Suddaby, 2006).

Diante do exposto, a configuração de aglomerados empresariais, conforme se observa no Polo Gastronômico de Santa Felicidade, é inserido como fenômeno empírico para estudar essa relação. A seguir, é apresentado o procedimento metodológico que foi utilizado para a condução desta pesquisa. 
Metodologia

Conforme Demo (1985, p. 19), "metodologia é uma preocupação instrumental. Trata das formas de se fazer Ciência. Cuida dos procedimentos, das ferramentas, dos caminhos". Consonante a isso, corroboram Sá-Silva, Almeida e Guindani (2009), bem como Saccol (2009), ao apontarem que a conduta de pesquisa a ser adotada está condicionada ao objeto de estudo e à respectiva problemática, assim como a dimensão epistemológica adotada pelo pesquisador, a qual irá fornecer diretrizes para a escolha dos métodos e técnicas mais adequados.

Dessa forma, definimos como objeto de pesquisa o setor turístico-gastronômico de Santa Felicidade, na cidade de Curitiba, constituído por restaurantes, adegas, chocolaterias e demais estabelecimentos ligados à atratividade turística existente na localidade. O objeto foi escolhido devido a sua representatividade turística, cultural e socioeconômica, sendo observado mediante recorte seccional com avaliação longitudinal, no período de 1878 a 2020, a partir de uma perspectiva teórica institucionalista, que visa a contextualização da evolução histórica e dos fatores institucionais presentes no fenômeno.

Em relação ao posicionamento epistemológico, foi adotado o apontamento de Saccol (2009, p. 262), no qual menciona que "a epistemologia interpretativista é construtivista, supondo que todo o nosso conhecimento sobre a realidade depende das práticas humanas e é construído por meio da interação entre as pessoas e o mundo no qual vivemos, sendo transmitido em um contexto social", culminando assim, na estratégia de pesquisa qualitativa (Creswell, 2010). A pesquisa documental foi utilizada como método, que conforme acepção de Sá-Silva, Almeida e Guindani (2009, p. 5) é tida como "um procedimento que se utiliza de métodos e técnicas para a apreensão, compreensão e análise de documentos dos mais variados tipos", mediante coleta de dados empíricos secundários (Flick, 2013).

O levantamento documental foi realizado entre os meses de novembro de 2019 a março de 2020, por meio de consulta ao motor de busca Google, utilizando palavras-chaves referentes ao Bairro de Santa Felicidade, direcionando acesso a sítios da Associação do Comércio e Indústria de Santa Felicidade [ACISF], Prefeitura Municipal de Curitiba [PMC], Instituto Municipal de Turismo [IMT], dos estabelecimentos gastronômicos, Instituto de Pesquisa e Planejamento Urbano de Curitiba [IPPUC], entre outros.

Foram ainda consultadas as redes sociais Facebook, Instagram e a plataforma de vídeos Youtube. Em relação a conteúdo impresso, tivemos acesso a três livros: Entre quatro panelas (Hubner, 2007), cujo conteúdo é a biografia de Flora Madalosso Bertolli, fundadora e proprietária dos restaurantes Madalosso; a obra Santa Felicidade, Cascatinha, Butiatuvinha, São João e Lamenha Pequena (Fenianos, 2006), uma coletânea sobre os bairros de Curitiba; e a ainda Santa Felicidade, o bairro italiano de Curitiba: um estudo sobre restaurantes, rituais e (re)construção de identidade étnica (Maranhão, 2014), uma dissertação de mestrado que culminou em livro, compondo, assim, a coleção teses do Museu Paranaense. Com isso, a 
pesquisa abrangeu conteúdos de cunho institucional, jornalístico, biográfico e documentos oficiais, em recursos disponibilizados de forma online, impressa e audiovisual.

Para o tratamento dos dados, foi adotada a técnica de análise de conteúdo temática de documentos proposta por Bardin (2009/1977), a qual Minayo, Deslandes e Gomes (2002) concordam, em que a organização da análise deve iniciar com a pré-análise do conteúdo, seguido da exploração do material, tratamento dos resultados e interpretação, ocorrendo, assim, a codificação, categorização e inferência dos dados.

Com base nessa proposta, a pré-seleção do conteúdo se deu por meio de leitura flutuante. Posteriormente, seguiu-se com a leitura aprofundada, realizada em paralelo com a perspectiva teórica adotada. Vale ressaltar que esse processo não ocorreu de maneira linear, mas em um movimento de "ir e vir", ora dos documentos para teoria, ora da teoria para os documentos. Dessa forma, os documentos foram catalogados e codificados por meio de recortes temáticos. A exploração dos materiais foi encerrada quando ocorreu a saturação dos dados (Flick, 2009). Uma síntese dos documentos utilizados é apresentada na Tabela 1.

Assim, foi possível chegar à definição do escopo teórico, bem como identificar as categorias analíticas empreendedorismo institucional e instituições. Para cada categoria analítica foi estabelecida a definição constitutiva operacional de análise.

A categoria analítica empreendedorismo institucional foi entendida como uma ação intencional, consciente e inovadora realizada por atores que possuem os recursos suficientes para criar ou modificar uma instituição, buscando atingir o interesse individual ou de uma coletividade (DiMaggio, 1988). Tal categoria operacionalizada por meio de análise documental, a partir da leitura e interpretação de documentos referentes ao bairro em questão, possibilitando, desse modo, a identificação de ações de empreendedorismo institucional desenvolvidas pelos atores.

A categoria instituições, por outro lado, compreendeu estruturas ou processos sociais que tendem a ser permanentes, porém não imutáveis. Além disso, as instituições são orientadas por elementos reguladores, normativos e cultural-cognitivos, levando em consideração aspectos relacionados a símbolos, comportamentos, atividades e recursos. Portanto, em alguns momentos, são responsáveis por restringir ações e em outros agem capacitando atividades e atores (Scott, 2008/1995). Por meio de análise documental, a partir da leitura e interpretação de documentos elencados, foram identificados os pilares institucionais resultantes do empreendedorismo institucional exercido pelos atores neste setor. 
Tabela 1 - Catálogo de documentos utilizados na análise

\begin{tabular}{|c|c|}
\hline Fonte Acessada & Tipo de Conteúdo \\
\hline Adega Caliari & História da empresa; modernização da produção de vinhos (I) \\
\hline Assembléia Legislativa do Estado do Paraná & $\begin{array}{l}\text { Reforça a importância da ACISF; projeto do uso de gás natural de cozinha nos } \\
\text { empreendimentos gastronômicos (I) }\end{array}$ \\
\hline $\begin{array}{l}\text { Associação do Comércio e Indústria de Santa } \\
\text { Felicidade }\end{array}$ & $\begin{array}{l}\text { Diversos: criação da associação; forma de atuação; enfrentamento à } \\
\text { pandemia da Covid-19 (I) }\end{array}$ \\
\hline Entre quatro panelas* & $\begin{array}{l}\text { Apresenta a trajetória pessoal e profissional de Flora Madalosso, } \\
\text { proprietária dos restaurantes Madalosso (B) }\end{array}$ \\
\hline $\begin{array}{l}\text { Santa Felicidade, Cascatinha, Butiatuvinha, } \\
\text { São João e Lamenha Pequena* }\end{array}$ & Origem dos imigrantes; herança cultural; primeira reivindicação (0) \\
\hline Instituto Municipal de Turismo & Dados sobre a primeira igreja e primeira escola da Colônia (l) \\
\hline \multirow{3}{*}{$\begin{array}{l}\text { Instituto de Pesquisa e Planejamento Urbano } \\
\text { de Curitiba }\end{array}$} & - Evolução econômica da Colônia, inicialmente de base agrícola (l) \\
\hline & $\begin{array}{l}\text { - Lei Estadual no. 1581/1916, referente criação do Distrito Administrativo/Judiciário } \\
\text { de Santa Felicidade (L) }\end{array}$ \\
\hline & - Decreto n: 774/1975, referente criação do Bairro de Santa Felicidade (L) \\
\hline Jornal Bem Paraná & Inauguração novo centro gastronômico (J) \\
\hline Jornal Folha de São Paulo & Primeiro hotel do Bairro (J) \\
\hline Jornal Gazeta do Povo & $\begin{array}{l}\text { Motivos que levaram à criação da Festa do Frango, Polenta e Vinho; } \\
\text { Estabelecimentos gastronômicos da família Madalosso e inovações no cardápio (J) }\end{array}$ \\
\hline Paróquia São José e Santa Felicidade & $\begin{array}{l}\text { História do bairro e dos imigrantes; influência da igreja sobre a Colônia; } \\
\text { festas tradicionais (l) }\end{array}$ \\
\hline \multirow{3}{*}{ Prefeitura Municipal de Curitiba } & - Contexto histórico da cidade e do bairro; imigração (l) \\
\hline & $\begin{array}{c}\text { - Lei Municipal n. 13.035/2008, a qual denomina a ACISF como entidade de utilidade } \\
\text { pública (L) }\end{array}$ \\
\hline & $\begin{array}{c}\text { - Lei Municipal n. 15123/2017 referente criação do polo gastronômico de Santa } \\
\text { Felicidade (L) }\end{array}$ \\
\hline Restaurante Cascatinha & Tradição familiar; negócios representados pela terceira geração (l) \\
\hline Restaurante Portal & Inicialmente uma casa de marmita; mudou sua configuração em virtude da demanda (I) \\
\hline $\begin{array}{l}\text { Santa Felicidade, o bairro italiano de Curitiba: } \\
\text { um estudo sobre restaurantes, rituais e (re) } \\
\text { construção de identidade étnica* }\end{array}$ & Diversos: história do bairro; comércio; atividade gastronômica; cultura (0) \\
\hline Secretaria Municipal de Saúde de Curitiba & Normas para funcionamento de estabelecimentos voltados à gastronomia (I) \\
\hline Vídeo [Youtube]: 140 anos de Santa Felicidade & $\begin{array}{l}\text { Chegada dos primeiros imigrantes na Colônia; } \\
\text { construção comunitária da primeira igreja (l) }\end{array}$ \\
\hline Vinhos Dall'Armi & Uso de tecnologias na fabricação de vinho (l) \\
\hline Vinhos Santa Felicidade & 0 incremento de maquinários aumentou a diversidade de produtos (I) \\
\hline
\end{tabular}

Nota: Os dados foram obtidos em sites diversos, plataforma Youtube e Instagram, com exceção das fontes sinalizadas com *, que são referentes a livros impressos. As marcações compostas pelas letras (B), (I), (J), (L) e (0) sinalizam o tipo de conteúdo, sendo respectivamente: Biográfico; Institucional (empresas privadas, órgãos públicos municipais e estaduais, associação e entidade religiosa); Jornalístico; Lei e Outros (obra de aspecto histórico resultante de pesquisa acadêmica). 
De acordo com estas definições constitutivas, tais categorias analíticas foram tratadas para gerar os resultados apresentados na próxima seção. Em suma, a Figura 1 expressa o processo metodológico percorrido nesta pesquisa.

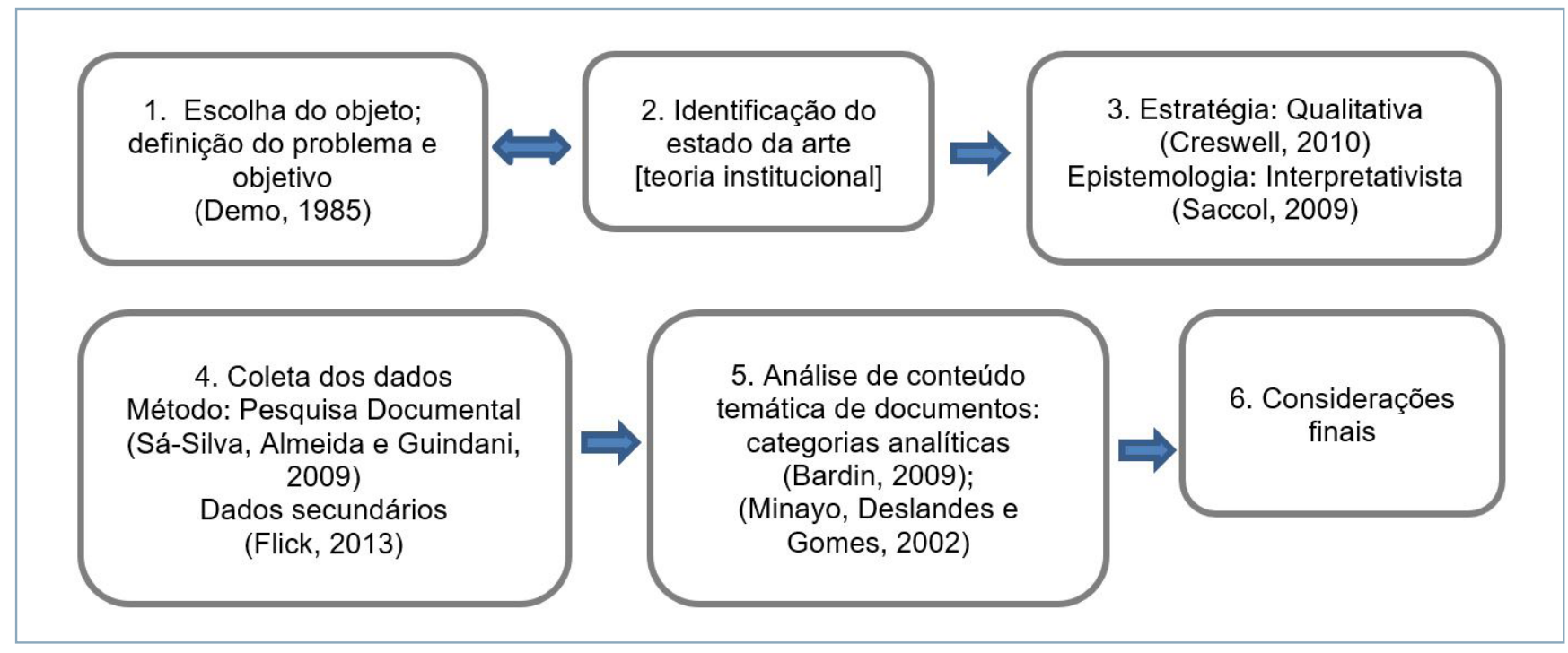

Figura 1. Etapas da Pesquisa

Fonte: Elaborado pelos autores.

\section{Análise de dados e discussão dos resultados}

Ao longo da pesquisa percebeu-se a importância do contexto histórico e social. Foram considerados diversos atores e a necessidade de uma busca sobre elementos que compuseram a história de formação do Bairro de Santa Felicidade, para que assim fosse possível compreender o status quo. Dessa forma, optou-se, primeiramente, por introduzir uma contextualização histórica.

\section{Contexto histórico: o caso em estudo}

Em 1854, após emancipação política do Estado do Paraná, um novo cenário surge na cidade de Curitiba com o fluxo de imigrantes europeus. Os primeiros italianos chegam em Curitiba em 1872, e no ano de 1878 é criada a colônia de Santa Felicidade (Curitiba, n.d.). Unindo forças, as primeiras 15 famílias efetuaram a compra de um terreno, de propriedade de Antônio e Felicidade Borges, a quem se atribui o nome do bairro, em referência a uma homenagem prestada pelas famílias italianas (Maranhão, 2014).

A região até então conhecida como Taquaral recebeu imigrantes italianos provenientes principalmente das regiões de Vêneto e Trento, que foram se estabelecendo nas fazendas da região e em pouco tempo somavam 200 famílias. Trouxeram consigo uma herança cultural, a produção de vinhos, queijos e hortifrutigranjeiros. Surgia, assim, a Colônia de Santa Felicidade (Fenianos, 2006). 
Ainda segundo esse autor, em 1880, a comunidade local fez um pedido ao governo para que uma estrada pudesse ser elo entre a cidade e a Colônia, estrada essa que viria a ser a atual Avenida Manoel Ribas. Assim, tornou-se rota comercial, pela qual os imigrantes levavam a produção para ser comercializada no centro da cidade. Segundo Maranhão (2014, p. 53), "diariamente, nas primeiras horas da manhã, partiam as colonas em suas carroças abarrotadas de lenha, cereais como feijão e milho, legumes e verduras frescas [...]". Conforme registro no site do IPPUC (n.d.):

Por muitos anos, a referida Colônia dedicou-se ao trabalho agrícola,
principalmente com o cultivo de milho, feijão, trigo, hortaliças e, também,
à criação animal em pequena escala, com produção de leite, queijo e
salame. A produção resultante era comercializada "na cidade" através
de carroças conduzidas pelos colonos, que seguiam entoando canções
italianas pela antiga Estrada da Colônia, onde hoje está localizada a
Avenida Manoel Ribas [...]. A dedicação dos imigrantes italianos e
seus descendentes contribuiu para a expansão econômica surgindo
um comércio diversificado e prestação de serviços com armazéns,
produção de queijos, vinhos e gastronomia, tornando a região dinâmica
e singular.

Em relação à religião e educação, a primeira igreja e a primeira escola datam de 1891 e 1899, respectivamente (IMT, n.d). Os imigrantes italianos, com forte devoção católica, diante da distância a ser percorrida para chegar até a atual Catedral Basílica Menor de Nossa Senhora da Luz dos Pinhais, no centro de Curitiba, inicialmente reuniam-se na casa de dois moradores da Colônia para realizar orações, leituras e catequisar as crianças. Aos poucos o espaço ficou pequeno, e com isso 70 famílias se uniram para construir uma pequena capela de madeira. Posteriormente, o missionário italiano Padre Colbacchini chega a Curitiba em 1886, com o objetivo de atuar junto aos imigrantes. Ao mudar-se para Santa Felicidade em 1889, percebe que o espaço estava pequeno para a quantidade de fiéis, e com isso a necessidade de construir uma nova igreja, concluída em 1891. Mais tarde, em 1926, foi ampliada e, em 1937 transformada em Paróquia, recebendo o nome do Padroeiro São José. Todavia, em 2013, torna-se Paróquia São José e Santa Felicidade. Quanto à escola paroquial, esta foi inaugurada em 1900, e desde então é administrada pelas religiosas do Sagrado Coração de Jesus, onde atualmente funciona o Colégio Imaculada Conceição (Paróquia São José e Santa Felicidade, n.d.).

Conforme disponibilizado no site do IPPUC (n.d.)., "[...] em 1916, fica criado, através da Lei Estadual n: 1581/1916, o Distrito Administrativo/ Judiciário de Santa Felicidade, caracterizando-se como um dos distritos mais antigos de Curitiba. Em 1975, o Decreto n. 774 criou o Bairro Santa Felicidade [...]" (IPPUC, n.d.). 


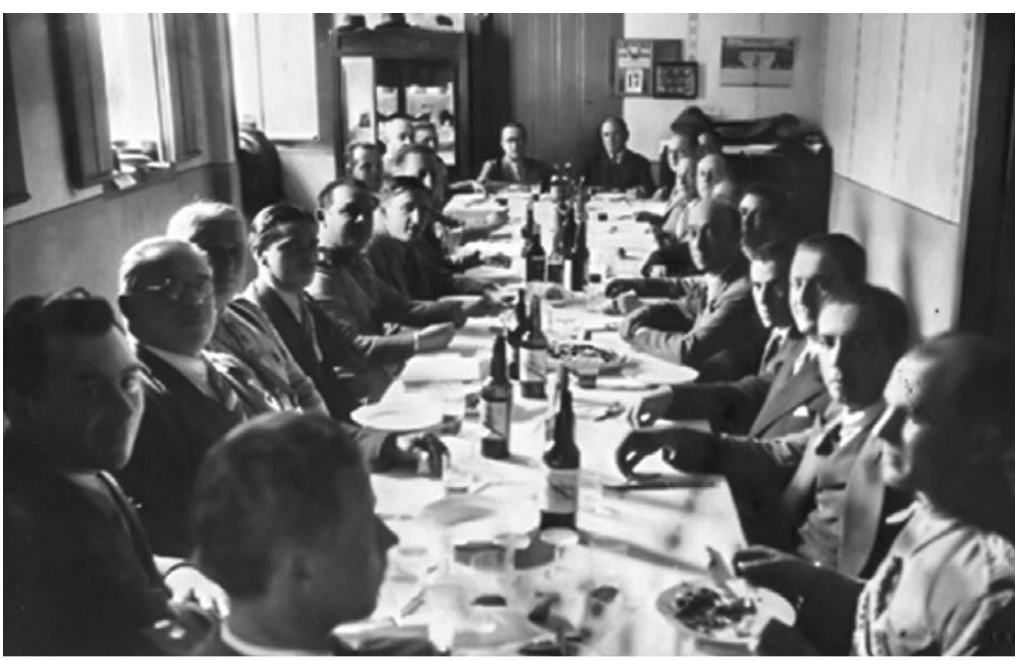

Interventor Manoel Ribas e autoridades políticas almoçando na pequena sala do Armazém da casa dos Arcos. Foto de 1945.

Imagem 1. Foto de Almoço sob Encomenda na Casa dos Arcos (1945)

Fonte: Grupo do Facebook Santa Felicidade Antigamente (2014, novembro 03).

Recuperado em 10 maio, 2020, de https://www.facebook.com/SantaFelicidade.Mozzilli/

De acordo com Maranhão (2014), as primeiras tentativas do empreender gastronômico surgem pequenas, sendo a comida servida na casa dos colonos e muitas vezes com a necessidade de encomenda. Nesse cenário, os restaurantes Iguaçu, Cascatinha e Casa do Arcos são empreendimentos que surgem ao final da década de 1940 (ver Imagem 1).

Em 1949, conforme pontua Hubner (2007, p. 68), "a Colônia de Santa Felicidade já tinha aproximadamente quatro mil habitantes, uma igreja, uma escola, um armazém de secos e molhados, um moinho onde se comprava a farinha e uma farmácia".

Outro importante acontecimento na Colônia foi a criação da Festa da Uva, a qual teve sua primeira edição em 1959. E, posteriormente, em 1982, a realização da primeira Festa do Vinho, atualmente conhecida como Festa do Frango, Polenta e Vinho (Paróquia São José e Santa Felicidade, n.d.).

No período compreendido entre as décadas de 1960 e 1980, novos empreendimentos gastronômicos entram em funcionamento, tais como: o Restaurante Durigan, o Restaurante Velho Madalosso, em 1963, com apenas 24 lugares e, em 1970, o Novo Madalosso, restaurante que viria a configurar-se na década de 1990 como o maior restaurante do continente americano, marca registrada por três anos consecutivos no Guiness Book (Hubner, 2007). Em 1965 a Avenida Manoel Ribas foi asfaltada, contribuindo para o aumento de fluxo na região. Neste mesmo ano, o Restaurante Veneza é inaugurado e na sequência, em 1967, o Restaurante San Remo. Ainda na década de 1970 surgem os restaurantes dançantes: Roda D’ Àgua, Toscana, Status e Mezza Notte Night Club. Em 1984 foi aberto o restaurante Peixe Frito, uma nova opção para apreciadores de frutos do mar (Maranhão, 2014). Depois, em 1989, o Restaurante Portal, inicialmente uma casa de marmitas (Restaurante Portal, n.d.) e em 1991 tem-se os Restaurantes Castello Trevizzo e Porta Romana (Maranhão, 2014). 
Conforme o apontamento de Maranhão (2014, p. 67), "em Santa Felicidade, desde a década de 1970, toda uma indústria de turismo cresceu em torno dos restaurantes, vinícolas e do comércio de móveis e artesanato em vime". Entre as produtoras de vinho estão a família Strapazzon, proprietária da marca Vinhos Santa Felicidade e as famílias Caliari, Durigan, Dall'Armi e Madalosso, que imprimem seus nomes como marca nos rótulos de seus produtos.

Com a grande concentração de restaurantes, em 1987 é criada a ACISF, com o objetivo de reivindicar melhorias para o Bairro junto à Prefeitura de Curitiba (Maranhão, 2014). A associação realiza intermediação entre os empresários locais e órgãos públicos, além de estabelecer parcerias que permitem o desenvolvimento e capitalização de recursos, fomentam parcerias e promovem eventos diversos (ACISF, n.d.).

Em 1994 já era notório o impacto gerado pela atividade turística-gastronômica da região, como observa Maranhão (2014, p. 117), "[...], são esses grandes restaurantes que atraem para Santa Felicidade 30.000 turistas a cada final de semana e que somados faturam em média 80 milhões de dólares ao ano".

O primeiro hotel foi inaugurado em 2004 (Folha de São Paulo, 2004), e atualmente pertence a rede Accor, utilizando a bandeira Ibis Styles. Mantendo sua atratividade turística ao longo dos anos, em 27 de novembro de 2017, cria-se o Polo Gastronômico de Santa Felicidade, conforme Lei Municipal n. 15123 (Curitiba, 2017). Mais recentemente, em 2018, foi inaugurado o centro gastronômico Rialto Villa Gastrômica, abrigando 17 lojas (Browne, 2018).

Santa Felicidade, atualmente, além dos consagrados restaurantes, vinícolas, adegas, hotel e amplo comércio local, conta com agências bancárias, unidade de saúde, postos de combustível, cartório e fórum, integrando uma infraestrutura privilegiada.

\section{Empreendedorismo institucional no polo gastronômico}

No processo de análise, foi possível identificar algumas ações de empreendedorismo institucional, descritas a seguir:

(a) Solicitação de uma via de acesso entre a Colônia e o centro de Curitiba: esta ação resultou no estabelecimento de um comércio entre a Colônia e o centro da cidade, que alavancou a comercialização dos produtos, permitindo aos imigrantes aumento de renda e geração de empregos;

(b) Comercialização dos produtos da Colônia: primeiramente a produção dentro da colônia tinha como objetivo suprir a demanda interna. O excedente, ainda produzido de forma artesanal, passou a ser comercializado na cidade. Esse modelo de comércio se estende desde a formação da colônia até meados da década de 1970. A partir desse momento, com a maior concentração de restaurantes, desenvolveu-se ao longo dos anos seguintes um comércio voltado ao turismo gastronômico. Com isso, o modo artesanal de produção, desde os pratos servidos nos restaurantes até a produção de vinhos, foi aos poucos sendo modernizado. 
(c) Construção da Igreja: os imigrantes italianos, ao chegarem em Santa Felicidade, mantiveram os pilares de sua cultura sustentados pelo tripé família, trabalho e religião. Diante da necessidade de manutenção da fé e a dificuldade de acesso até a igreja mais próxima, empreendem um trabalho de construção comunitária que durou 3 anos. Conforme vídeo, disponível na plataforma YouTube, Paróquia São José e Santa Felicidade (2018), pode-se observar detalhes desse momento:

\begin{abstract}
[...] e em três anos conseguiram construir a igreja. É impressionante, como em tão pouco tempo, um grupo de pessoas relativamente pobres conseguiram construir. [...] na construção da lgreja, a areia era do rio e as pedras do alicerce eram trazidas das pedreiras. Eles traziam essas pedras nas carroças e a areia, as mulheres é, com avental, com baldes, alguma coisa, iam trazendo aquela areia. Todos pra ajudarem na construção. E os tijolos eram feito maçico e eram cozidos nos fornos que se usava para fazer o pão [...]. Então todo mundo fazia o pão em casa e daí aproveitavam quem podia fazer 15, 20 tijolos daqueles maciços, eram tijolos grandes de mais ou menos [...] 25, 30 centímetros, pesado, pesavam uns cinco, seis quilo cada um.
\end{abstract}

(d) Criação dos primeiros restaurantes: outra característica é o perfil inovador, com o propósito de iniciar um novo negócio ou expandi-lo, nas quais suas ações afetam diretamente a economia local (Li, Feng, \& Jiang, 2006). Paralelo a essa visão apresenta-se como característica atores que focam na mudança da lógica até então predominante (Svejenova, Mazza, \& Planellas, 2007). Essa característica foi observada em alguns atores imersos no campo, que impulsionados pela necessidade de suprir um momento de instabilidade financeira, inovaram ao começar algo inexistente até então na Colônia, uma vez que abriram as portas de suas próprias casas para a comercialização de refeições.

(e) Criação da Festa da Uva: a partir de um pedido feito ao vigário por um membro da comunidade, em 1959, foi possível realizar a primeira Festa da Uva, cujo objetivo era tornar a Colônia mais conhecida, divulgando a cultura local, além de comercializar as uvas e demais alimentos produzidos internamente. Em 2020, a festa atingiu a $62^{a}$ edição. Essa ação de empreendedorismo institucional corrobora Battilana (2006), em que o indivíduo pode atuar na implementação de algo novo.

(f) Adequação de cardápio: em virtude da construção do Novo Madalosso e consequente ampliação da capacidadade de atendimento, surgiu a necessidade de modificar dois pratos: a polenta cremosa e o frango ensopado. Os pratos foram então alterados para polenta frita e frango a passarinho, respectivamente. Conforme menciona um do sócios, "foi uma necessidade do momento que deu muito certo. É o que representa a nossa história" (Mori, 2019). Além dessa adequação, Flora Madalosso foi responsavél pela inclusão de um novo item, o frango prensado (Maranhão,2014).

(g) Primeiras divulgações em nível nacional: o restaurante Madalosso participou da Feira da Providência, nas cidades do Rio de Janeiro (1974 e 1975) e Brasília (1976), onde eram montadas estruturas para servir os participantes desse evento. No mesmo período, viagens regulares para as capitais do Brasil foram realizadas como forma de divulgar o restaurante. Como resultado, o Bairro de Santa Felicidade ficou conhecido nacionalmente. 
Tais ações de divulgação impulsionaram o número de visitantes, favorecendo todos os estabelecimentos da região.

(h) Criação de um novo nicho de mercado: com a ampliação do restaurante Madalosso e um trabalho exaustivo de divulgação, o estabelecimento, além de providenciar o serviço de alimentação, torna-se também um centro de confraternização atendendo eventos diversificados (Hubner, 2007). Esse comportamento ao longo dos anos passa a ser adotado pelos concorrentes.

(i) Criação da Festa do Frango, Polenta e Vinho: esta segunda festa surge em 1982, diante da necessidade de comercializar os produtos que não foram vendidos durante a Festa da Uva daquele ano. O impacto foi causado por um grande volume de chuvas durante a realização da festa (Denck, 2019). Ambas festividades estão consolidadas e são realizadas anualmente no Bosque São Cristóvão, organizadas pela Paróquia São José e Santa Felicidade. Todavia, em virtude da pandemia da Covid-19, a 38. edição que seria realizada em 2020 foi cancelada.

(j) Criação de uma Associação Comercial: segundo Czarniawska (2009), as ações podem ser realizadas tanto por um indivíduo como por um grupo de pessoas. Movidos pela necessidade de reivindicar melhorias para o bairro, proprietários de restaurantes e de outros estabelecimentos comerciais na região se uniram para criar uma associação representativa, a qual impulsionou novas ações de empreendedorismo institucional a partir da institucionalização dos padrões de comportamento empreendedor.

(k) Ações voltadas para a manutenção do turismo: nesse aspecto percebe-se a participação de diversos atores e ações para fomentar o turismo na região, incluindo sinalização turística, divulgação de passeios, concursos culturais, manutenção das Festas da Uva e Festa do Frango, Polenta e Vinho, exposições fotográficas, construção de monumentos, ampliação de pontos da linha de turismo no Bairro, lançamento do Guia Curta Santa Felicidade, Posto de Informação Turística, entre outros.

(I) Ações voltadas ao enfrentamento da pandemia da Covid-19: a ACISF tem realizado em seu site a divulgação de orientações provenientes da Prefeitura Municipal de Curitiba e Associação Comercial do Paraná [ACP], que visam a adequação conforme legislação em vigor e procedimentos tidos como corretos para este momento. Tem-se como diretrizes o horário permitido de funcionamento, a capacidade de lotação, o distanciamento mínimo entre pessoas, o uso de álcool em gel, o uso de máscaras, entre outras. Além das ações envolvendo segurança e saúde, a ACISF juntamente com a ACP e a Cooperativa de Crédito SICOOB Sul disponibilizaram aos seus associados uma linha de crédito em caráter emergencial, oferencendo capital de giro com carência de até um ano (ACISF, n.d.). Além de todo o protocolo seguido para funcionamento dos empreendimentos, foi identificada uma nova ação de empreendedorismo institucional, com a implementação por parte de alguns restaurantes: o serviço de Delivery Express. 
A Figura 2 abaixo apresenta as principais ações de empreendedorismo institucional identificadas ao longo do período de 1878 a 2020.

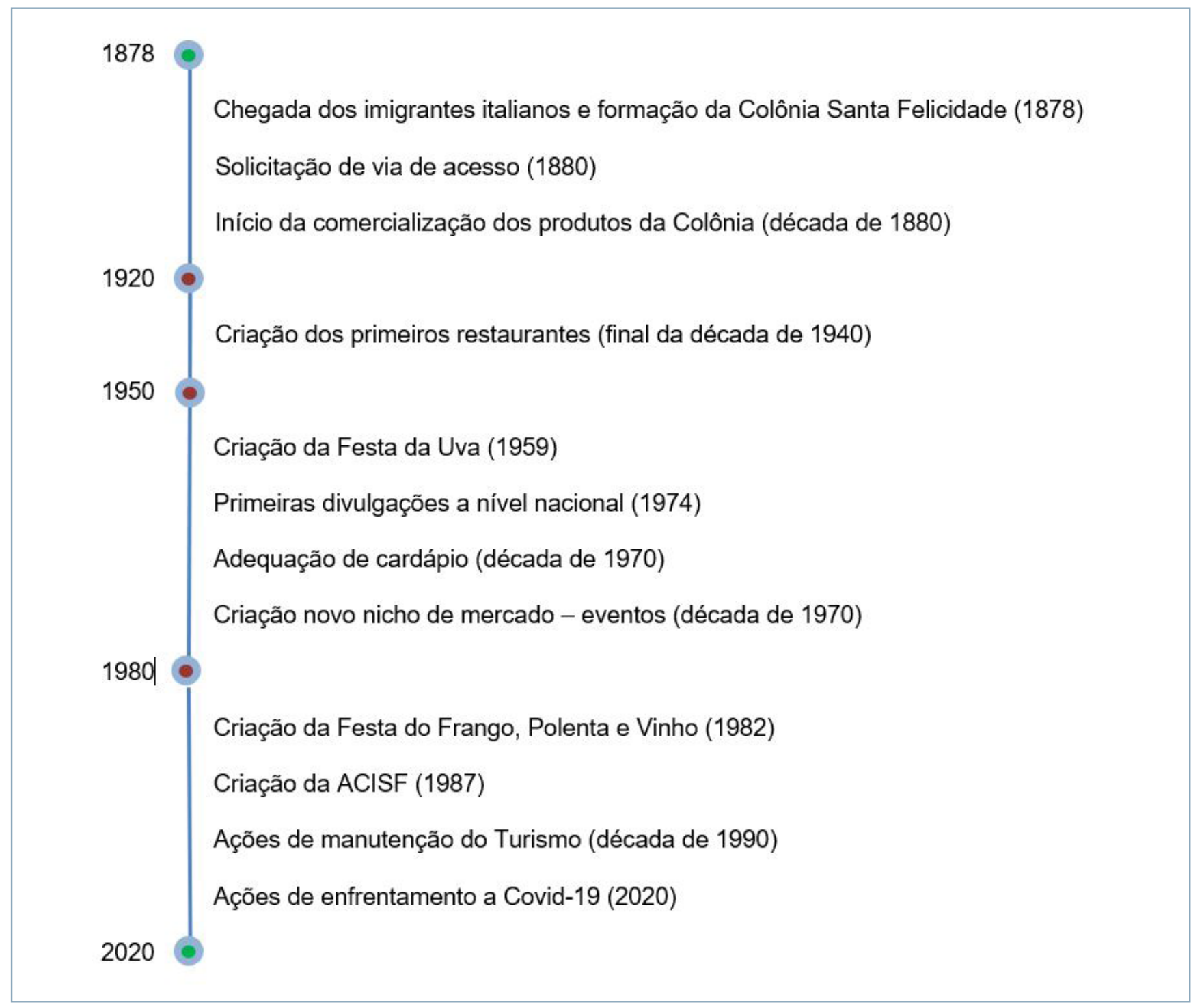

Figura 2. Ações de Empreendedorismo Institucional no Período de 1878 a 2020

Fonte: elaborado a partir da análise de conteúdo de documentos.

Assim, destaca-se que a partir do embasamento teórico foi possível identificar a importância de alguns atores-chaves que, de posse dos recursos necessários e com características voltadas à inovação e ao senso de mudança, atuaram como empreendedores institucionais, alterando a realidade local e contribuindo para criação e a transformação de instituições.

Percebe-se, então, que as ações empreendedoras realizadas e reproduzidas ao longo do tempo foram evoluindo do nível da ação para o nível das instituições, ou seja, o fenômeno da configuração e formação do Polo Gastronômico de Santa Felicidade pode ser explicado a partir de ações de empreendedorismo institucional (Battilana, 2006; Smothers, Murphy, Novicevic \& Humphreys, 2014) que puderam ser capturadas a partir da análise 
de dados documentais. É óbvio que uma limitação da pesquisa está em deixar escapar algumas ações empreendedoras que foram desenvolvidas ao longo da história do Polo e que hoje são refletidas pelas instituições vigentes. Desta forma, o arcabouço teórico sobre empreendedorismo institucional é suficiente para descrever o caso, uma vez que a grande maioria das ações são aspectos de criação e de manutenção institucional que podem ser observadas no Polo. Ou seja, os empreendedores institucionais querem manter a posição no campo organizacional e quando se sentem ameaçados, como no contexto de pandemia pela Covid-19, articulam-se para criar novas ações que poderão, ao serem dadas como certas no contexto de referência dos agentes, ser adotadas como padrão de práticas de gestão, institucionalizando-se com o tempo.

A limitação da pesquisa mencionada pode ser superada mediante realização de entrevistas junto aos empreendedores institucionais, classificando-os em agentes indutores de ações institucionais e agentes induzidos imersos no campo organizacional constituído pelo setor turístico-gastronômico de Santa Felicidade.

Conforme indicam os dados, o período entre 1878 até a década de 1970 compõe uma fase de criação e implementação de instituições. Por outro lado, a partir da década de 1980 até o ano de 2019 percebe-se uma fase mais inclinada à manutenção dessas instituições. Todavia, no ano de 2020, com a influência da pandemia da Covid-19, inicia-se um momento de readequação das instituições, com perspectiva de criação de novas instituições e possibilidade de interrupção de outras.

O empreendedorismo institucional desenvolvido neste Polo foi marcado por ações que estabeleceram visões compartilhadas, nas quais a operacionalização ocorreu dentro de um contexto institucional que foi sendo estabelecido ao longo do tempo. A presença de entidades públicas fortaleceu as ações dos empreendedores institucionais, bem como a criação da ACISF contribuiu para reforçar a união de atores e a troca de conhecimentos. E, à medida que a rede de relacionamentos aumentou, as ações de empreendedorismo institucional foram fortalecidas, impulsionando a institucionalização setorial.

\section{Instituições constituídas no polo gastronômico}

Após a identificação das ações de empreendedorismo institucional como resultado das articulações manifestadas pelos atores sociais, foi possível também identificar as principais instituições criadas ao longo do processo de formação do Polo Gastronômico de Santa Felicidade. O surgimento dessas instituições se deu ao longo do período observado, compreendido entre 1878 a 2020. As instituições regulativas, normativas e culturais-cognitivas, como já visto anteriormente em Scott (2008/1995), podem ser consideradas estruturas ou processos, que funcionam como regras de orientação e padrões de conduta.

Através da análise documental, no pilar regulativo, cuja base de legitimidade é definida por algo legalmente sancionado, foi possível identificar as instituições regulativas presentes no setor. Conforme os dados 
da pesquisa, o comércio e a economia de Santa Felicidade que inicialmente eram sustentados pela atividade de base agrícola, foram sendo alterados com o passar dos anos.

Entre os marcos importantes, considera-se a instituição dos primeiros restaurantes ao final da década de 1940 e, posteriormente, em 1970, o processo de industrialização da cidade de Curitiba e o crescimento do turismo local, situações essas que contribuiram para o atual cenário de Santa Felicidade. Nesse sentido, foram observadas as três instituições regulativas que impactam diretamente o setor analisado a partir da década de 1990.

A primeira instituição regulativa identificada foi uma consequência da própria instalação dos estabelecimentos gastronômicos que passaram a estar sujeitos a regras formalmente impostas pelo governo municipal, por meio da Secretaria Municipal de Saúde de Curitiba [SMS], atuante desde 1992, e representada pela Vigilância Sanitária [VISA]. Assim, o direito de funcionamento dos estabelecimentos passou a estar condicionado ao cumprimento de ações em conformidade com as estipuladas pela VISA.

Nesse sentido, foram efetuadas ações de eliminação ou mitigação de riscos à saúde e à segurança alimentar, que compreende o trabalho de inspeção em estabelecimentos como restaurantes, pizzarias, churrascarias, lanchonetes, feiras, entre outros (SMS, n.d.).

Ainda conforme a SMS (n.d.), o efeito pode ocorrer em caráter educativo, ou tendo como objetivo a "[...] emissão de parecer técnico sanitário para liberação de alvará de localização e funcionamento de estabelecimentos de interesse à saúde, emissão de licença sanitária [...]". Para tal, são observados "a estrutura e instalações físicas, recursos humanos, fluxos e rotinas técnico-operacionais que envolvam: pessoas, materiais, artigos, utensílios, máquinas, equipamentos, insumos e resíduos, bem como as condições de higiene e limpeza, que tragam segurança aos produtos e serviços prestados".

A segunda instituição regulativa surge ao enfatizar o papel desempenhado pela ACISF, por meio da Lei Municipal n. 13.035, de 16 de dezembro de 2008, que declarou a ACISF como entidade de utilidade pública (Curitiba, 2008). Conforme relata Reiss (2008), "a ACISF desenvolve programas que visam o fortalecimento e o bem-estar da comunidade, como, por exemplo, o projeto que instaurou o uso de gás natural nas cozinhas dos estabelecimentos gastronômicos de Santa Felicidade" e ainda "[...] tem como finalidade social a defesa das atividades empresariais de seus associados, o fortalecimento do regime econômico e mercado da região, assistindo seus associados e os representado judicial ou extra judicialmente".

Essa lei foi expressiva para o setor, uma vez que confere legitimidade à ACISF como associação atuante junto ao setor comercial de Santa Felicidade, representando, assim, o empresariado local. 
Tabela 2 - Instituições regulativas

\begin{tabular}{cccc}
\hline Instituição & Entidade Burocrática & Indicador & Base de Legitimidade \\
\hline $\begin{array}{c}\text { Regras para o funcionamento } \\
\text { de estabelecimentos ligados ao } \\
\text { setor de alimentação }\end{array}$ & $\begin{array}{c}\text { Secretaria Municipal de Saúde } \\
\text { (Atuação VISA) }\end{array}$ & $\begin{array}{c}\text { Emissão de alvará e licença } \\
\text { sanitária }\end{array}$ & $\begin{array}{c}\text { Cumprimento de normas de } \\
\text { segurança alimentar }\end{array}$ \\
\hline $\begin{array}{c}\text { Reconhecimento da associação } \\
\text { Gastronomia como vocação } \\
\text { local incentivada }\end{array}$ & Prefeitura Municipal de Curitiba & Lei Municipal 13.035 (2008) & Utilidade pública \\
\hline
\end{tabular}

Fonte: Elaborado a partir da análise de conteúdo de documentos.

Por fim, a terceira instituição regulativa reflete-se diretamente nas ações de empreendedorismo institucional desenvolvidas ao longo da formação do bairro, as quais foram incorporadas e ganharam concretude através da Lei Municipal n. 15.123, de 27 de novembro de 2017, que instituiu o Polo Gastronômico de Santa Felicidade, cujo objetivo é a promoção da atividade econômica, atração de investimentos, divulgação, entre outras ações voltadas ao fomento do setor.

A Tabela 2 apresenta a síntese das instituições regulativas identificadas na formação do Polo Gastronômico de Santa Felicidade. Em relação ao pilar normativo, este possui como base legitimadora regras moralmente aceitas (Scott, 2008/1995). Assim, foram identificadas três instituições normativas.

Por muitos anos a Igreja foi responsável por prescrever o comportamento das famílias italianas. Essa instituição normativa teve sua consolidação com base no tripé família, religião e trabalho. A Igreja forneceu também as diretrizes catecismo, idioma, manutenção de costumes e educação, que permanecem valorizadas e mantidas até hoje como padrões dados como certos.

A segunda instituição normativa refere-se à ética nos negócios. Conforme relatado em Maranhão (2014, p. 123):

\begin{abstract}
Conhecemos muito bem o trabalho dos nossos amigos proprietários do restaurante... Um trabalho sempre voltado para bem servir a sua freguesia, um trabalho de fôlego de muitos anos. Conhecemos também o caráter e finura destas pessoas, há mais de 25 anos e de maneira nenhuma poderemos admitir que fomos taxados de qualquer adjetivo que venha a denegrir a excelente imagem que possuem. Um acidente de trabalho que pode acontecer a qualquer um de nós, não deve ser motivo para especulações.
\end{abstract}

Esse trecho de entrevista faz alusão ao fechamento temporário de um restaurante, efetuado em virtude de uma intoxicação alimentar. Nesse contexto, a autora menciona a existência de duas relações concomitantes entre os restaurantes: a concorrência e o estabelecimento de relações solidárias. Essa relação torna-se plausível uma vez que a reputação de um empreendimento interfere diretamente no setor como um todo (Maranhão, 2014). 


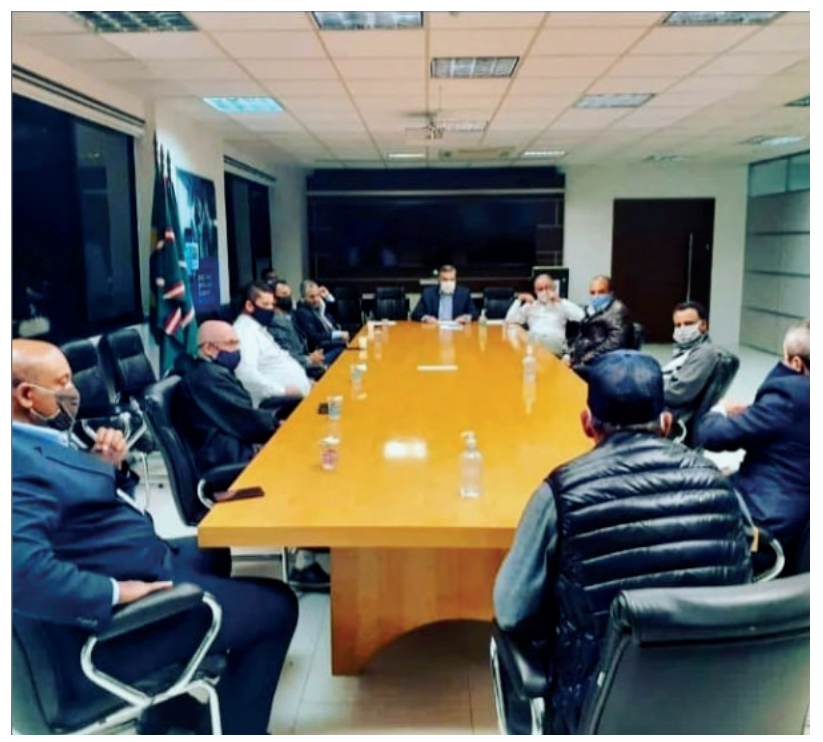

Imagem 2. Foto de Reunião da ACISF com Entidades e Sindicatos do Setor de Alimentos e Bebidas, para a Definição de Normas de Reabertura dos Empreendimentos (2020)

Fonte: ACISF (2020, maio 06). Reunião [Instagram]. Recuperado em 08 maio, 2020, de https://www. instagram.com/acisf_sanfe/?hl=pt-br

A terceira instituição normativa é identificada como associativismo. Antes mesmo da ACISF ter sido declarada como utilidade pública (conforme visto anteriormente em instituições regulativas), após a sua criação e com o crescimento e profissionalização dos restaurantes, essa associação ganhou representatividade enquanto instituição.

Entre algumas das vantagens de ser um associado está o acesso ao crédito financeiro, consultoria jurídica, convênios e parcerias (ACISF, n.d.). Outro indicador é a normatização de condutas. Mais recentemente, por conta da pandemia da Covid-19, a ACISF tem fornecido diretrizes aos empresários do setor para minimizar os impactos sofridos, conforme mostra a Imagem 2.

A Tabela 3 apresenta uma síntese das instituições normativas identificadas na formação do Polo Gastronômico de Santa Felicidade.

Tabela 3 - Instituições normativas

\begin{tabular}{cccc}
\hline Instituição & Entidade Burocrática & Indicador & Base de Legitimidade \\
\hline $\begin{array}{c}\text { Disseminação de } \\
\text { comportamentos moralmente } \\
\text { aceitos }\end{array}$ & $\begin{array}{c}\text { Paróquia São José e Santa } \\
\text { Felicidade }\end{array}$ & Costumes & Religiosidade \\
\hline Ética nos negócios & Restaurantes & Reputação & Respeito mútuo e relações de \\
proximidade
\end{tabular}

Fonte: Elaborado a partir da análise de conteúdo de documentos. 
Com relação às instituições culturais-cognitivas, foram identificadas sete incidências. A base de legitimidade ocorre pelo compartilhamento de práticas empresariais, dadas como certas, logo, culturalmente amparadas. Conforme Scott (2008/1995, p. 59), "uma concepção cultural-cognitiva das instituições enfatiza o papel central desempenhado pela construção socialmente mediada de uma estrutura comum de significado".

Nesse sentido, a primeira instituição cultural-cognitiva apresenta-se sob a forma de empreendedorismo, o qual a partir de empresas precursoras foi difundido de forma mimética e rapidamente ampliou o setor gastronômico. Nota-se a manutenção de valores e tradições arraigados desde a fundação da Colônia, percebidos em certos padrões como o ambiente mais familiar, menos formal e de proximidade com o cliente.

A segunda instituição cultural-cognitiva reflete o conservadorismo observado no setor, marcado por empreendimentos familiares que são geridos por distintas gerações de uma mesma família. Entre os casos observados, está o da Família Madalosso, que detêm em Santa Felicidade sete empreendimentos, sendo os restaurantes: Velho Madalosso, Restaurante Madalosso, Famiglia Fadanelli, Mezza Note, Dom Antonio e Anello e a panificadora PaniCiello, refletindo o trabalho constante de três gerações (Mori, 2019). Da mesma forma, são mantidos por três gerações os negócios da Família Trevisan, proprietários dos Restaurantes Cascatinha e Castello Trevizzo (Restaurante Cascatinha, n.d). A mesma situação foi observada em adegas e vinícolas. Conforme informação no site da Adega Caliari (n.d.), "na época de moagem e engarrafamento, Moacir e sua esposa, Maria Sunta, além dos filhos, contam com a colaboração de parentes".

Já a terceira instituição cultural-cognitiva reflete o cardápio composto pelo trinômio: polenta frita, frango a passarinho e risoto de miúdos. Esses itens foram aderidos por todos os restaurantes de base italiana em Santa Felicidade. Outro item também foi posteriormente instituído, de acordo com Maranhão (2014, p. 151), "finalmente, o frango prensado [...] fez tanto sucesso que 'começou a tirar a clientela dos outros restaurantes', os quais rapidamente também o adotaram". Fica explícito nesse trecho que a manutenção do cardápio ocorreu de forma mimética por conta da concorrência existente entre estes estabelecimentos.

A quarta instituição cultural-cognitiva apresenta-se sob a forma da adesão tecnológica, influenciando diretamente os estabelecimentos da região. No caso dos vinhos, inicialmente produzidos para consumo próprio, ao passarem para um estágio de comercialização se mantiveram de forma artesanal por muitos anos, no entanto, com a modernização do setor e a disponibilidade de aparatos tecnológicos, houve uma diversificação de produtos e aumento da produção. Conforme observa-se no site Vinhos Santa Felicidade (n.d.):

Nos dias de hoje, o vinho é engarrafado no mesmo local de sua fundação, passando da forma artesanal para modernidade de maquinários e mão de obra diferenciados. Tivemos um aumento em nosso leque de produtos oferecidos ao mercado, agregando assim, maior valor à marca.

Observado também no site Vinhos Dall'Armi (n.d.), "hoje a Dall'Armi conta com uma estrutura tecnológica capaz de fabricar os chamados vinhos 
"coloniais" [...]". Alguns, ainda, embora em escalas menores de adesão tecnológica, também apontam o processo de transição, conforme cita o site Adega Caliari (n.d.):

Muita coisa mudou desde a chegada dos primeiros imigrantes italianos. A tecnologia, mesmo que modesta, está presente nas fábricas de vinho. Na época dos avós de Moacir Caliari, as uvas eram moídas com os pés e o processo todo manual. Hoje, até por uma questão de higiene, não é possível fazer da mesma forma. "Acompanhamos as técnicas mais rústicas e tudo é artesanal. Temos apenas máquinas para moer as uvas. Nas cantinas, o último contato direto com as uvas é na colheita", explica o filho Paulo César Caliari, que preserva os costumes dos pais.

No caso dos restaurantes, o frango que antes chegava vivo e era abatido nos fundos do estabelecimento e preparado em um fogão a lenha de duas bocas (Hubner, 2007), ganha, agora, uma nova dinâmica com a implementação de aparatos tecnológicos. As cozinhas são ampliadas, passam a possuir gás natural e equipamentos industriais, favorecendo diretamente a ampliação da capacidade de atendimento desses serviços gastronômicos.

A quinta instituição cultural-cognitiva refere-se à inovação de serviços, por meio de um novo nicho de atuação, o de eventos. O Restaurante Madalosso foi o responsável pelo start a partir da década de 1970, sendo a prática logo copiada pelos demais estabelecimentos. Os restaurantes de Santa Felicidade recebem os mais diversificados tipos de eventos, como casamentos, formaturas, festas de aniversário, eventos corporativos, políticos, entre outros.

A sexta instituição cultural-cognitiva refere-se à imagem de Santa Felicidadecomo destino turístico-gastronômico. Aatividadeturística, conforme apontado anteriormente na introdução desta pesquisa, contribui em diversos aspectos na economia de uma dada região. Em Santa Felicidade, observa-se que esse trabalho é resultante de ações desenvolvidas ao longo da história de formação desse bairro por diferentes atores que desempenharam papéis importantes na consolidação dessa imagem, sendo eles os empresários, PMC, IMT, SEBRAE e ACISF.

Para exemplificar, em números, o Restaurante Madalosso, que é o segundo maior do mundo, atualmente com 4.630 lugares, atende em média 3.000 refeições aos domingos, registra um consumo de três toneladas de polenta frita por semana, e uma estimativa de que 50\% a $60 \%$ de seu público seja de fora da cidade.

Por fim, a última instituição cultural-cognitiva identificada é expressa pelo atendimento. Questões de qualidade parecem estar atreladas à cultura dos imigrantes italianos e também à concorrência no mercado. Nesse sentido, aparecem expressões como: mesa farta, relações de proximidade com o cliente e presteza. Ainda considera questões como a manutenção de fornecedores, visando sempre um mesmo padrão.

Logo, dão ênfase tanto à qualidade do serviço como do próprio alimento. Esse cuidado reflete diretamente no comportamento dos clientes, por meio da fidelização. São famílias nas quais diferentes gerações mantém a tradição de almoçar num mesmo restaurante. O olhar voltado à excelência no atendimento também é adotado por adegas e vinícolas, sendo comum em 
Santa Felicidade a degustação de vinhos, sucos, queijos, salames e geléias, em um ambiente acolhedor e de proximidade.

A Tabela 4 apresenta uma síntese das instituições culturais-cognitivas identificadas na formação do Polo Gastronômico de Santa Felicidade.

Tabela 4 - Instituições culturais-cognitivas

\begin{tabular}{cccc}
\hline Instituição & Entidade Burocrática & Indicador & Base de Legitimidade \\
\hline Empreendedorismo & Atores precursores & Mimetismo & Dificuldades financeiras \\
\hline $\begin{array}{c}\text { Conservadorismo } \\
\text { (empreendimentos familiares) }\end{array}$ & Restaurantes, Adegas e Vinícolas & $\begin{array}{c}\text { Número de empreendimentos } \\
\text { pertencentes a uma mesma } \\
\text { família }\end{array}$ & Tradição \\
\hline $\begin{array}{c}\text { Cardápio com base no trinômio: } \\
\text { polenta frita, frango a passarinho } \\
\text { e risoto de miúdos }\end{array}$ & Restaurantes & Mimetismo & Concorrência \\
\hline $\begin{array}{c}\text { Adesão Tecnológica } \\
\text { Restaurantes, Adegas e Vinícolas }\end{array}$ & utilização de aparatos \\
tecnológicos & Modernização do Setor e \\
ampliação da capacidade de \\
produção.
\end{tabular}

Fonte: Elaborado a partir da análise de conteúdo de documentos.

Ao retomar o embasamento teórico, conforme defendido por Jepperson (1991), percebe-se, através dos dados observados, uma tendência à manutenção das instituições anteriormente elencadas. É possível argumentar, com base nas fases de institucionalização propostas por Lawrence, Winn e Jennings (2001), que esse setor já passou pelas etapas de inovação e difusão, e atualmente encontra-se legitimado, conferido por uma regra formal, em virtude da Lei municipal n. 15123, conforme apresentado no pilar regulativo de Scott (2008/1995).

Ao considerarmos os mecanismos de mudança isomórfica defendidos por DiMaggio e Powell (2005/1983), observa-se que a institucionalização deste Polo Gastronômico, quando expressa pela Lei supracitada, reflete diretamente a existência de um mecanismo de ordem coercitiva. Entretanto, é necessário considerar todo o processo de formação do bairro até o atingimento da configuração atual.

Dessa forma, além da coersão, são observados também mecanismos normativos, em razão do aumento de demanda nesses estabelecimentos e com isso a necessidade de profissionalização e associativismo. E ainda, mecanismos isomórficos miméticos, uma vez que a similaridade no setor é identificada em muitos momentos, conforme observado nos itens triviais que rapidamente foram adotados no cardápio de muitos restaurantes.

Assim, finalizadas as discussões acerca das categorias analíticas, empreendedorismo institucional e instituições, percebe-se que houve mudanças e uma evolução no campo organizacional do Polo Gastronômico 
de Santa Felicidade desde a sua criação, como a alteração de atores antes centrais e agora reconfigurados em um novo arranjo. De uma forma simplista, num primeiro momento, logo após a chegada das primeiras famílias italianas, o núcleo existente era regido pela atividade agrícola familiar, na qual a Igreja desenvolvia um papel central na organização da Colônia.

Em um segundo momento, com o aumento do número de restaurantes e demais estabelecimentos ligados à gastronomia, percebe-se uma nova configuração no campo e, somado a isso, a criação de uma associação comercial no Bairro, além do envolvimento de órgãos públicos de fomento à atividade turístico-gastronômica que marcam também esse novo período.

Ainda com base nos conceitos defendidos por DiMaggio e Powell (2005/1983), e Scott (2008/1995), ao que tudo indica, a manutenção institucional percebida nesse campo empírico, através de comportamentos homogêneos, tem propiciado a sobrevivência das organizações inseridas no setor e conferido legitimidade. Essa observação vai ao encontro do que defendem Baratter, Ferreira e Costa (2010, p. 247), ao argumentarem que "campos organizacionais altamente estruturados se direcionam à homogeneização de práticas e de estruturas organizacionais".

Dessa forma, futuramente pretende-se apresentar a evolução do referido campo organizacional, com fundamentação teórico-empírica de maneira mais elaborada, incluindo fontes primárias de pesquisa.

\section{Considerações finais}

Ao estudar o setor turístico-gastronômico do Bairro de Santa Felicidade na cidade de Curitiba, por meio da pesquisa documental e da análise de conteúdo temática, fundamentada na teoria institucional, foi possível atingir o objetivo da pesquisa, ou seja, identificar alguns fatores institucionais que influenciaram a formação do Polo Gastronômico no Bairro de Santa Felicidade.

O estudo sinaliza que, em paralelo à mudança histórica do ambiente, foram surgindo atores sociais com as habilidades e recursos necessários para desempenhar um forte papel como empreendedores institucionais. Ao longo do tempo, as ações culminaram em melhorias de infraestrutura do bairro, impulsão do comércio baseado inicialmente na produção colonial e posterior criação e expansão de estabelecimentos gastronômicos. Dessa forma, a região destaca-se por dois aspectos importantes: o primeiro corresponde a um setor organizacional bem consolidado e o segundo se relaciona a sua atratividade turística.

Como resultado, instituições foram criadas e modificadas ao longo do tempo investigado. Com isso, a atual configuração do campo organizacional é resultante desse processo institucional, principalmente decorrente das mudanças estabelecidas a partir do final da década de 1940 e institucionalizadas ao longo dos últimos 40 anos. Porém, percebe-se que, embora este campo organizacional seja notório e reconhecido desde meados da década de 1970, visto a grande concentração de restaurantes e sua atratividade turística, este tem sua legitimidade oficializada apenas em 2017 , 
por meio da Lei Municipal n. 15123, com a criação do Polo Gastronômico de Santa Felicidade (Curitiba, 2017).

Os achados apresentem convergência com a literatura adotada, especialmente no que tange a influência do empreendedor institucional na criação e manutenção de instituições, a adoção de padrões e a busca de legitimidade. No entanto, é preciso enfatizar que os resultados, ora apresentados, são ainda preliminares, pois configuram estudo em andamento. Por este motivo, ressalta-se o interesse dos pesquisadores em manter agenda complementar futura sobre a temática exposta, por meio de aplicação de entrevistas semiestruturadas aos fundadores e/ou proprietários de estabelecimentos no eixo que compõe o turismo gastronômico da região supracitada, devendo os entrevistados serem escolhidos de forma intencional.

Desta forma, este artigo não tem a pretensão, e nem poderia, de exaurir as questões de pesquisa que podem ser elaborados em torno do objeto de estudo, todavia, pretende-se com esse trabalho apresentar o caminho metodológico da pesquisa qualitativa, por meio de estudo de caso com triangulação de dados, de modo a fornecer novos insights para aprofundar esse estudo e subsidiar outros.

Nesse sentido, acreditamos que a maior contribuição da pesquisa reside na aproximação estabelecida entre teoria e campo empírico, ao aumentar o debate sobre como fatores institucionais são capazes de direcionar organizações, com olhar voltado para elementos que, combinados, são pouco explorados, sendo: a análise de forma setorial longitudinal, de organizações em contexto turístico, através da perspectiva institucional.

Por essa razão, sugere-se a realização de novos estudos empíricos, sejam eles em outros Polos Gastronômicos, ou em outros tipos de aglomerados, analisados de forma setorial, no intuito de identificar se há similaridades com o encontrado nesta pesquisa, ou ainda se há fatores aqui não observados e que se sobrepõem a outros estudos institucionais. Ressalta-se que a realização da contextualização histórica, de forma seccional longitudinal, se mostrou fundamental para o levantamento dos marcos institucionais, sendo aconselhado seu uso na condução dos novos estudos.

\section{Referências}

Adega Caliari. (n.d.). Vinhos colonial. Recuperado em 20 janeiro, 2020, de https:// www.adegacaliari.com.br/nossa-historia

Arruda, L. R. V. (2016). Empreendedorismo institucional: o caso de Joaquim Murtinho. Revista Cadernos de Estudos Sociais e Políticos, 5(9), 27-48. doi: https:// doi.org/10.12957/cesp.2016.21263

Associação do Comércio e Indústria de Santa Felicidade. (n.d.). Sobre. Recuperado em 01 maio, 2020, de http://acisf.com.br/

Avrichir, I., \& Chueke, G. V. (2011). Empreendedorismo institucional: uma análise de caso no setor de energia elétrica Brasileiro. Revista de Administração Mackenzie, 12(6), 140-164. doi: https://doi.org/10.1590/S1678-69712011000600007 
Baratter, M. A., Ferreira, J. M., \& Costa, M. C. (2010). Empreendedorismo institucional: características da ação intencional. Perspectivas Contemporâneas. Edição Especial, 237-266.

Bardin, L. (2009). Análise de conteúdo (5a ed., L. A. Reto \& A. Pinheiro, Trad.). Lisboa: Edições 70. (Obra original publicada em 1977).

Barretto, M., \& Rejowski, M. (2009). Considerações epistemológicas sobre segmentação: das tipologias turísticas à segmentação de mercado. In A. Panosso Netto \& M. G. R. Ansarah (Eds.). Segmentação do mercado turístico: estudos, produtos e perspectivas. Barueri, SP: Manole.

Battilana,J.(2006). Agencyandinstitutions:theenabling roleofindividuals' socialposition. Organization, 13(5), 653-676. doi: https://doi.org/10.1177/1350508406067008

Leca, B., Battilana, J ., \& Boxenbaum, E. (2009). Agency and institutions: a review on institutional entrepreneurship. Academy of Management Annals, 3, 65-107.

Berger, P. L., \& Luckmann, T. (2004). A construção social da realidade: tratado de Sociologia do conhecimento. Petrópolis, RJ: Vozes. (Obra original publicada em 1966).

Borges, D. E. (2014). Respostas estratégicas ao ambiente institucional e a performance exportadora: o caso dos empreendedores do setor vitivinícola da campanha gaúcha-RS. Dissertação de mestrado, Universidade Federal de Santa Maria, Santa Maria, Rio Grande do Sul, Brasil. Recuperado em 15 junho, 2020, de http://search.ebscohost.com/login.aspx?direct=true\&db=edsbas\&AN=edsbas.395 10829\&lang=pt-br\&site=eds-live\&scope $=$ site

Browne, B. M. (2018). Centro gastronômico inspirado em Veneza em Santa Felicidade. Recuperado em 27 janeiro, 2020 de Jornal Bem Paraná, de https:// www.bemparana.com.br/blog/mesadividida/post/centro-gastronomico-inspiradoem-veneza-em-santa-felicidade\#.XjszLmhKjlU

Brunstein, J., Rodrigues, A. L., \& Kirschbaum, C. (2008). Inovação social e empreendedorismo institucional: a ação da Ong "Ação Educativa" no campo educacional da cidade de São Paulo. Organizações \& Sociedade, 15(46), 119-136. doi: https://doi.org/10.1590/S1984-92302008000300006

Curitiba. (2008). Lei municipal no 13.035, de 16 de dezembro de 2008. Declara de utilidade pública a Associação do Comércio e Indústria de Santa Felicidade - ACISF. Recuperado em 29 janeiro, 2020, de https://leismunicipais.com.br/a/pr/c/curitiba/ lei-ordinaria/2008/1303/13035/lei-ordinaria-n-13035-2008-declara-de-utilidadepublica-a-associacao-do-comercio-e-industria-de-santa-felicidade-acisf

Curitiba. (2017). Lei municipal n. 15123, de 27 de novembro de 2017. Cria o "Polo Gastronômico de Santa Felicidade" e dá outras providências. Recuperado em 21 janeiro, 2020, de https://mid-turismo.curitiba.pr.gov.br/2019/10/pdf/00003802.pdf

Curitiba. (2017, novembro 25). Lei favorece ampliação do Polo Gastronômico de Santa Felicidade. Recuperado em 22 junho, 2020, de https://www.curitiba.pr.gov.br/ noticias/lei-favorece-ampliacao-do-polo-gastronomico-de-santa-felicidade/44260

Curitiba. (n.d.). História - Imigração. Recuperado em 21 janeiro, 2020, de https:// www.curitiba.pr.gov.br/conteudo/historia-imigracao/208

Creswell, J. W. (2010). Projeto de Pesquisa: Métodos qualitativo, quantitativo e misto. (3 ed., M. F. Lopes, Trad.). Porto Alegre: Artmed.

Czarniawska, B. (2009). Emerging institutions: pyramids or anthills? Organization Studies, 30(4), 423-441. doi: https://doi.org/10.1177/0170840609102282 
Demo, P. (1985). Introdução à metodologia da Ciência. São Paulo: Atlas.

Denck, D. (2019). Tradicional Festa do Frango, Polenta e Vinho de Santa Felicidade esquenta o inverno. Recuperado em 29 janeiro, 2020, de Jornal Gazeta do Povo, de https://clube.gazetadopovo.com.br/noticias/outros/festa-frango-polenta-vinhosanta-felicidade/

DiMaggio, P. J. (1988). Interest and agency in institutional theory. In L. Zucker (Ed.). Institutional patterns and organizations. Cambridge: Ballinger.

DiMaggio, P. J, \& Powell, W. W. (2005). A gaiola de ferro revisitada: isomorfismo institucional e racionalidade coletiva nos campos organizacionais. Revista de Administração de Empresas, 45(2), 74-89. (Artigo original publicado em 1983).

Domingues, J. M. (2001). A sociologia de Talcott Parsons. Niterói: Editora da Universidade Federal Fluminense.

Eisenstadt. S. N. (1980). Cultural orientations, institutional entrepreneurs, and social change: comparative analysis of traditional civilizations. American Journal of Sociology, 85(4), 840-869.

Falaster, C., Zanin, L. M., \& Guerrazzi, L. A. (2017). Teoria institucional na pesquisa em turismo: novas oportunidades de uma teoria em evolução. Revista Brasileira de Pesquisa em Turismo, 11(2), 270-293.

Fenianos, E. E. (2006). Santa Felicidade, Cascatinha, Butiatuvinha, São João e Lamenha Pequena - siamo tutti buona gente (Nol.10, Coleção Bairros de Curitiba). Curitiba: Univer Cidade.

Folha de São Paulo. (2004). Curitiba: Santa Felicidade inaugura o seu 10. hotel em agosto. Recuperado em 27 janeiro, 2020, de https://www1.folha.uol.com.br/folha/ turismo/noticias/ult338u4187.shtml

Flick, U. (2013). Introdução à metodologia de pesquisa: um guia para iniciantes. (M. Lopes, Trad.). Porto Alegre: Penso.

Flick, U. (2009). Uma introdução à pesquisa qualitativa. Porto Alegre: Bookman.

França, A. S. T. (2009). Talcott Parsons: apontamentos para uma análise institucional. Cadernos de Pesquisa Interdisciplinar em Ciências Humanas, 10(97), 181-204. doi:https://doi.org/10.5007/1984-9851.2009v10n97p181

Freitas, C. H. G. (2018). "Cozinha medieval”: regionalidade e pós-modernidade em um restaurante gastronômico de uma cidade global. Dissertação de mestrado. Universidade Federal de Uberlândia. Minas gerais, Uberlândia, Brasil. Recuperado em 03 maio, 2020, de http://search.ebscohost.com/login.aspx?direct=true\&db=eds bas\&AN=edsbas.371E7403\&lang=pt-br\&site=eds-live\&scope=site

Gândara, J. M. G., Gimenes, M. H. S. G., \& Mascarenhas, R. G. T. (2009). Reflexões sobre o turismo gastronômico na perspectiva da sociedade dos sonhos. In A. Panosso Netto \& M. G. R. Ansarah (Eds.). Segmentação do mercado turístico: estudos, produtos e perspectivas. Barueri, SP: Manole.

Goulart, S., Vieira, M. M. F., \& Carvalho, C. A. (2005). Universidade e desenvolvimento local: uma abordagem institucional. Porto Alegre: Sagra-Luzzatto.

Hall, P. A., \& Taylor R. C. R. (1996). Political science and the three new institutionalisms. Political Studies, XLIV, 1-32. doi: https://doi.org/10.1111/j.1467-9248.1996. tb00343.x 
Hall, R. H. (2004). Organizações: estruturas, processos e resultados (8a ed., R. Galman Trad.). São Paulo: Pearson Prentice Hall. (Obra original publicada em 1972). Hardy, C., \& Maguire, S. (2008). Institutional entrepreneurship. In R. Greenwood, C. Oliver, K. Sahlin \& R. Suddaby (Orgs.). Handbook of Organizational Institutionalism. London: Sage.

Holanda, L. A. de. (2003). Formação e institucionalização do campo organizacional do turismo no Recife-PE. Dissertação de mestrado, Universidade Federal de Pernambuco, Recife, Pernambuco, Brasil. Recuperado em 30 janeiro, 2020, de https://repositorio.ufpe.br/handle/123456789/1157

Hubner, R. A. (2007). Entre quatro panelas. Curitiba: Hellograff.

Instituto de Pesquisa e Planejamento Urbano de Curitiba. (n.d.). Curitiba em dados: 1975 histórico do Bairro Santa Felicidade. Recuperado em 22 janeiro, 2020, de http://curitibaemdados.ippuc.org.br/

Instituto Municipal de Turismo. (2018). Dados e estatísticas. Recuperado em 22 junho, 2020, de https://turismo.curitiba.pr.gov.br/conteudo/dados-e-estatisticas/1724

Instituto Municipal de Turismo. (n.d.). Polo Gastronômico de Santa Felicidade. Recuperado em 21 janeiro, 2020, de https://turismo.curitiba.pr.gov.br/conteudo/ polo-gastronomico-de-santa-felicidade/2554

Jacometti, M., Castro, M., Gonçalves, S. A., \& Costa, M. C. (2016). Análise de efetividade das políticas públicas de Arranjo Produtivo Local para o desenvolvimento local a partir da teoria institucional. Revista de Administração Pública, 50(3), 425-454. doi: http://dx.doi.org/10.1590/0034-7612142712

Jepperson, R. L. (1991). Institutions, institutional effects, and institutionalism. In W. W. Powell \& P. J. DiMaggio (Eds.). The new institutionalism in organizational analysis (pp. 143-163). Chicago: The University of Chicago Press.

Lawrence, T. B., Winn, M. I., \& Jennings, P. D. (2001). The temporal dynamics of Institutionalization. The Academy of Management of Review, 26(4), 624-644. doi: https://doi.org/10.5465/amr.2001.5393901

Lawrence, T. B., \& Suddaby R. (2006). Institutions and institutional work. In S. R. Clegg, C. Hardy, T. B. Lawrence, \& W. R. Nord (Eds.). Handbook of organization studies. (2a. ed., pp. 215-254). London: Sage.

Lévesque, B. (2002). Les entreprises d'économie sociale, plus porteuses d'innovations sociales que les autres? Cahiers du CRISES, 0205(1), 01-27.

Lévesque, B. (2002). Les entreprises d'économie sociale, plus porteuses d'innovations sociales que les autres? Annales du Colloque du CQRS au Congrès de l'ACFAS, Montreal, CA, 1, 01-27.

Li, D. D., Feng, J., \& Jiang, H. (2006). Institutional entrepreneurs. American Economic Association, 96(2), 358-362.

Machado-da-Silva, C. L., Fonseca, V. S., \& Crubellate. J. M. (2010). Estrutura, agência e interpretação: elementos para uma abordagem recursiva do processo de institucionalização. Revista de Administração Contemporânea, Edição Especial, 77-107. doi: https://doi.org/10.1590/S1415-65552010000600005.

Maranhão, M. F. C. (2014). Santa Felicidade, o bairro italiano de Curitiba: um estudo sobre restaurantes, rituais e (re)construção de identidade étnica. Curitiba: Coleção Teses do Museu Paranaense. 
Meyer, J. W., \& Rowan, B. (1977). Institucionalized organizations: formal structure as myth and ceremony. American Journal of Sociology, 83(2), 340-363.

Minayo, M. C. S., Deslandes, S. F., \& Gomes, R. (2002). Pesquisa social: teoria, método e criatividade (21. ed.). Petrópolis, RJ: Vozes.

Ministério do Turismo. (2017). Turismo injetou US\$ 163 bilhões no Brasil em 2017. Recuperado em 12 dezembro, 2019, de www.turismo.gov.br/\%C3\%BAltimasnot\%C3\%ADcias/11037-turismo-injetou-us\$-163-bilh\%C3\%B5es-no-brasilem-2017.html

Mori, M. (2019). Como os Madalosso construíram um império gastronômico com 15 restaurantes, bares e padaria. Recuperado em 28 janeiro, 2020, de Jornal Gazeta do Povo, de https://www.gazetadopovo.com.br/bomgourmet/restaurantes/historiamadalosso-curitiba/

Mutch, A. (2007). Reflexivity and the institutional entrepreneur: a historical exploration. Organization Studies, 28(7), 1123-1140. doi: http://dx.doi. org/10.1177/0170840607078118

Nascimento, G. C., Rodrigues, V. J., \& Megliorini, E. (2010, novembro). Conceitos da teoria institucional: fonte propulsora de evolução para a gestão de desempenho. Anais do Congresso Brasileiro de Custos, Belo Horizonte, MG, Brasil, XVII.

Oliver, C. (1992). The antecedents of desinstitutionalization. Organization Studies, 13(4), 563-588. doi: https://doi.org/10.1177/017084069201300403

Paróquia São José e Santa Felicidade. (2018, novembro 23). 140 anos de Santa Felicidade [Youtube]. Recuperado em 27 janeiro, 2020, de https://www.youtube. $\mathrm{com} /$ watch?time_continue $=5 \& \mathrm{v}=14 \mathrm{z} 94 \mathrm{eHJghs} \&$ feature $=$ emb_logo

Paróquia São José e Santa Felicidade. (n.d.). Nossa História. Recuperado em 10 janeiro, 2020, de https://www.paroquiasantafelicidade.com/nossa-historia

Parsons, T. (1937). The structure of social action. New York: Macmillan.

Parsons, T. (1951). The social system. Glencoe: The Free Press.

Powell, W. W., \& DiMaggio, P. J. (1991). The new institutionalism in organizational analysis. Chicago: University of Chicago press.

Regatieri, R. P. (2019). Teoria da ação e teoria de sistemas em Talcott Parsons e Jürgen Habermas. Estudos de Sociologia, 2(25), 189-212. Recuperado em 15 junho, 2020, de https://periodicos.ufpe.br/revistas/revsocio/article/view/243767

Reiss, C. (2008). Assembléia reconhece utilidade pública de entidade em Santa Felicidade. Recuperado em 29 janeiro, 2020, de Assembléia Legislativa do Estado do Paraná, http://www.assembleia.pr.leg.br/comunicacao/noticias/assembleiareconhece-utilidade-publica-de-entidade-em-santa-felicidade

Restaurante Cascatinha. (n.d). Home. Recuperado em 01 maio, 2020, de https:// www.cascatinharestaurante.com/

Restaurante Portal. (n.d.). Sobre o restaurante. Recuperado em 01 maio, 2020, de http://www.restauranteportal.com.br/restaurante.php

Saccol, A. Z. (2009). Um retorno ao básico: compreendendo os paradigmas de pesquisa e sua aplicação na pesquisa em administração. Revista de Administração da UFSM, 2(2), 250-269. doi: http://dx.doi.org/10.5902/198346591555

Sá-Silva, J. R., Almeida, C. D., \& Guindani, J. F. (2009). Pesquisa documental: pistas teóricas e metodológicas. Revista Brasileira de História \& Ciências Sociais, 1(1), 01-15. 
Scott, R. W. (1992). Organizations: rational, natural, and open systems (3. ed.). New Jersey: Prentice-Hall. (Obra original publicada em 1981).

Scott, R. W. (2008). Institutions and organizations: ideas and interests (3a. ed.). Los Angeles: Sage Publications. (Obra original publicada em 1995).

Secretaria Municipal de Saúde. (n.d.). VISA Curitiba. Recuperado em 29 janeiro, 2020, de http://www.saude.curitiba.pr.gov.br/vigilancia/sanitaria/informacoesgerais/visa-curitiba.html

Serviço Brasileiro de Apoio às Micro e Pequenas Empresas. (2018). Como o Sebrae atua no segmento de Turismo. Recuperado em 10 dezembro, 2019, de https://m. sebrae.com.br/sites/PortalSebrae/segmentos/turismo/como-o-sebrae-atua,cdfc74 7f0a5af510VgnVCM1000004c00210aRCRD

Suddaby, R., Greenwood, R. (2005). Rhetorical strategies of legitimacy. Administrative Science Quarterly, 50(1), 35-67.

Smothers, J., Murphy, P. J., Novicevic, M. M., \& Humphreys J. H. (2014). Institutional entrepreneurship as emancipating institutional work: James Meredith and the Integrationist Movement at Ole Miss. Journal of Management History, 20(1), 114-134. doi: https://doi.org/10.1108/JMH-06-2012-0047

Svejenova, S., Mazza, C., \& Planellas, M. (2007). Cooking up change in haute cuisine: Ferran Adrià as an institutional entrepreneur. Journal of Organizational Behavior, 28, 539-561. doi: https://doi.org/10.1002/job.461

Thiollent, M. (2014). Estudos organizacionais: possível quadro referencial e interfaces. Revista Brasileira de Estudos Organizacionais, 1(1), 17-29. doi: https:// doi.org/10.21583/2447-4851.rbeo.2014.v1n1.28

Tolbert, P. S., \& Zucker, L. G. (1998). A institucionalização da teoria institucional. In S. Clegg, C. Hardy \& W. Nord (Eds.). Handbook de estudos organizacionais. (Vol. 1). São Paulo: Atlas.

Vasconcelos, F. C. (2004). A institucionalização das estratégias de negócios: o caso das start-ups na internet brasileira em uma perspectiva construtivista. Revista de Administração Contemporânea, 8(2), 159-179. doi: https://doi.org/10.1590/S141565552004000200009

Vinhos Dall'Armi. (n.d.). A história da Vinícola Dall'Armi. Recuperado em 09 janeiro, 2020, de https://vinhosdallarmi.com.br/historia.htm

Vinhos Santa Felicidade. (n.d.). História dos vinhos Santa Felicidade. Recuperado em 09 janeiro, 2020, de http://www.vinhosantafelicidade.com.br/novo/empresa.php Zaneti, T. B. (2012). Das panelas das nossas avós aos restaurantes de alta gastronomia : os processos sociais de valorização de produtos agroalimentares tradicionais. Dissertação de mestrado, Universidade de Brasília, Brasília, Distrito Federal, Brasil. Recuperado em 15 junho, 2020, de http://search.ebscohost.com/login.aspx?direct=t rue\&db=edsndll\&AN=edsndl.oai.union.ndltd.org.IBICT.oai.agregador.ibict.br.BDTD.oai. bdtd.ibict.br.UNB.hdl.10482.749.oai.repositorio.bce.unb.br.10482.12019\&lang=ptbr\&site=eds-live\&scope=site

Zucker, L. G. (1977). The role of institutionalization in cultural persistence. American Sociology Review, 42(5), 726-743.

Zucker, L. G. (1987). Institutional theories of organization. Annual Review of Sociology, 13, 443-464. doi: https://doi.org/10.1146/annurev.so.13.080187.002303 